\title{
6 \\ MOUNTAINS AND MOLEHILLS: SAMPLE SIZE IN ARCHAEOLOGICAL MICROSCOPIC STONE-TOOL RESIDUE ANALYSIS
}

\author{
Michael Haslam \\ Leverhulme Centre for Human Evolutionary Studies \\ University of Cambridge \\ Cambridge CB2 1QH, United Kingdom \\ Email:mah66@cam.ac.uk
}

\begin{abstract}
The passing of Thomas H. Loy in late 2005 presents an opportunity to reflect on the field of archaeological stone-tool microscopic residue analysis, of which Loy was a pioneer. This paper discusses one important and neglected aspect of residue studies from an historical perspective: reliance by residue analysts on small sample sizes. A review of stone-tool microscopic residue studies published over the first 30 years of the discipline (1976-2006) demonstrates that half of these examined 25 or fewer artefacts, with sample sizes of three or fewer artefacts being most common. In addition, sample sizes are shown to be decreasing in recent years. These findings have implications for the applicability of the novel data provided by residues to broader archaeological debates, and are discussed in relation to the specialisation of archaeological microscopic residue analyses. The review provides a caution against over-interpretation and emphasises the need for a more explicit link between sample sizes and research questions, while recognising the validity and usefulness of appropriately theorised studies of small numbers of artefacts.
\end{abstract}

\section{KEYWORDS}

residue analysis, microscopy, sample size, stone tools, Thomas H. Loy

\section{INTRODUCTION}

The passing in October 2005 of a pioneer of archaeological microscopic residue analysis, Thomas H. Loy, offers an opportunity to reflect on the historical trajectory of the field. Although building on earlier traceological work exemplified by Semenov (1964), the traditional origin date of the stone-tool microscopic residue technique is 1976, with the publication by Briuer of 'New clues to stone tool function: plant and animal residues' in American Antiquity. This was followed by the initiation of rigorous and multi-stranded investigation of blood residues by Loy (1983) and subsequent increased emphasis on starch grain residues and other plant microfossils (e.g. Loy et al. 1992). The residue analysis field is presently characterised by a growing diversity of approaches and geographic foci and extends to a time depth of well over 1,000,000 years (Dominguez-Rodrigo et al. 2001; Hardy and Rogers 2001), with this success owing in no small measure to Loy's influence.

This paper does not intend to provide an exhaustive historical overview, however, and instead takes this opportunity to examine a neglected issue of significance to current practice, namely the sample sizes employed by stone-tool residue analysts. This issue is discussed in the 
context of the role of novel scientific data within archaeological reconstructions, using a review of the archaeological microscopic stone-tool residue literature from 1976-2006. The aims of this review are twofold: first to ascertain the range of variation and any trends in the numbers of artefacts examined by analysts; and second to ask whether or not sample size has or should have a constraining influence on the conclusions drawn from a stone-tool residue study.

\section{SAMPLE SIZE IN MICROSCOPIC STONE-TOOL RESIDUE ANALYSIS}

Sampling issues have a long tradition in archaeological investigation (see outlines in Baxter 2003; Mueller 1975; Redman 1974; also Orton 2000). To assess residue study sample sizes for this study, an annotated list of stone-tool microscopic residue analyses published between 1976 and 2006 was assembled (see Appendix). Certain parameters were followed for inclusion, namely that the residue data must be from a published account of original research on archaeological stone artefacts using light microscopy. This excludes therefore publications that discuss residue findings but report no new results (e.g. Denham and Barton 2006; Villa et al. 2005; Wood 1998), as well as unpublished theses and manuscripts (e.g. Broderick 1982; Fullagar 1982; Furby and Loy 1994; Gorman 2000; Higgins 1988; Loy et al. 1999; Paull 1984; Petraglia et al. 2002) and residue studies not employing, or ambiguous about the use of, light microscopy (e.g. Anderson 1980; Anderson et al. 2004; Anderson-Gerfaud 1990; Cosgrove 1985; Loy and Nelson 1986; McBryde 1974; Morwood 1981; Nelson et al. 1986; Potter 1994; Robertson 1996). Care has also been taken to avoid double listing of separate publications that report the same results (e.g. Dodson et al. 1993 and Furby et al. 1993; Fullagar 1988 and 1989; Fullagar 1992 and Fullagar et al. 1998; Pearsall 2003, Pearsall et al. 2004 and Chandler-Ezell et al. 2006; Perry 2002 and 2005) and in these situations the more detailed study is listed.

The studies reviewed were from the English-language literature, as the vast majority of residue results have been published in English, although a limited number of studies exist in other languages (e.g. Babot 2001; Pagan Jimenez et al. 2005). The Appendix to this paper updates that provided in Haslam (2006b: Appendix 1), and the literature surveyed covers only those publications available up to the time of data compilation in mid-2006. A small number of publications appearing around or after this time are therefore not included. These restrictions are not expected to affect the conclusions of the survey to any significant degree, however the dynamic nature of the field emphasises the need for periodic review.

The key concern of most researchers using sampling theory is obtaining a representative sample that will allow quantification and extrapolation of results from a limited dataset to a larger (often unknown) population. A relevant distinction here is between target and sampled populations (Orton 2000:41), the former being the set of artefacts about which we wish to make statements, and the latter being the available artefacts from which we select pieces for analysis. The very notion of sampling implies a target population under investigation, although the myriad approaches for analysing archaeological objects may require a narrowing or broadening of this target depending on the interests of the archaeologist. If the sampled population contains biases (e.g. all analysed stone tools are from one site), then it may not be possible to make meaningful statements about a wider target population (e.g. the use of stone tools across all sites in a region). It is also difficult to assess the validity of statements about any population when sampling procedures are not explicitly discussed in published studies, as is the case for the large majority of those reviewed for this paper. For example, while the artefacts in Haslam (2003) were randomly selected, this fact was not reported in the published study, which simply lists the number of artefacts examined. Non-random sampling introduces further potential biases.

Data from the studies reviewed in the Appendix suggest that stone-tool microscopic residue analyses have yet to adequately address or account for the influence of sampling biases, or establish representative samples appropriate for the desired scale of analysis. Clearly, there have been both large (>2000 artefacts, e.g. Boot 1993; Briuer 1976) and very small (single artefact, e.g. Babot and Apella 2003; Fullagar 1993b; Loy 1985; Piperno, et al. 2004) samples investigated. 
Table 1. Summary statistics for the reviewed studies

\begin{tabular}{|c|c|c|c|}
\hline \multicolumn{4}{|c|}{ All studies } \\
\hline Total no. of studies & 96 & Standard deviation & 420.34 \\
\hline Total no. of analysed artefacts & 13025 & Median & 26 \\
\hline Mean no. of artefacts per study & 135.68 & Mode & 3 \\
\hline \multicolumn{2}{|c|}{24 largest studies } & \multicolumn{2}{|c|}{24 smallest studies } \\
\hline Total no. of analysed artefacts & 11514 & Total no. of analysed artefacts & 62 \\
\hline Mean no. of artefacts per study & 479.75 & Mean no. of artefacts per study & 2.58 \\
\hline Standard deviation & 750.93 & Standard deviation & 1.41 \\
\hline Median & 166.5 & Median & 3 \\
\hline Mode & 150 & Mode & 3 \\
\hline
\end{tabular}

Statistical analyses and graphical presentation of these numbers provide an initial perspective on the representativeness of the conclusions drawn from these studies. Table 1 outlines some basic descriptive statistics; as it examines sample sizes those studies not reporting such data are excluded. Where multiple studies are reported in a single paper they are treated separately, as indicated in the Appendix, giving a total of 96 sites in 91 publications. The table includes information on the entire selection as well as the 24 smallest and largest studies (comprising $25 \%$ of the total in each case) as a means of further clarifying the nature of the data.

The most obvious feature of the data is that the sample sizes are very heavily positively skewed (that is, towards small samples), as seen in the sequence of mean $>$ median $>$ mode. This is true of the sample as a whole as well as for the largest $25 \%$ of studies. Data for the smallest $25 \%$ of studies show a very slight negative skew in the sequence of mean $<$ median $=$ mode, but as the largest sample size in this data subset is five artefacts, this does not detract from the observed trend towards analyses of small samples. The most common sample size in the entire dataset (the mode), and therefore the most commonly reported microscopic residue artefact sample size, is three artefacts. The second most common sample size is a single artefact, and the third most common is two artefacts. Similarly, while the overall average is 136 artefacts per study, this figure is deceptive, as the standard deviation of 420 (more than three times the mean), and the median value of 26 clearly show. The influence of the higher outliers is also seen when the largest $25 \%$ of studies are considered, with one standard deviation (751) far exceeding the mean (480). Half of all studies have examined 25 or fewer artefacts.

The largest $25 \%$ of studies contains every residue study of over 70 artefacts and the chief impact on this dataset is made by the three studies (Boot 1993; Briuer 1976; Fullagar 1988) that exceed 1000 artefacts. Because of the strong positive skew, a more realistic view of past practice is provided by the smallest $25 \%$ of studies, with a mean sample size of 2.6 and standard deviation of 1.4. By way of comparison, the smallest $50 \%$ of studies have an average of 8.6 artefacts per study, again with a relatively large standard deviation of 7.2 (data not shown in Table 1). Additionally, the total number of stone artefacts examined microscopically for residues over the past three decades may be estimated at less than 15,000 worldwide, even allowing for those studies that are not included in Table 1 due to lack of published data. The three largest studies contribute over 7000 of these artefacts. Compared with other archaeological analytical methods and other lithic analysis techniques, the low total number of artefacts analysed and published globally to this point marks the field as a niche provider of archaeological information, and the focus on small samples warrants further investigation for its impact on the field.

Graphic presentations of numerical trends are more accessible than raw statistics alone, so these are combined in the remainder of this section. Figure 1 shows the spread of published sample sizes, with the $\mathrm{x}$-axis presenting two different scales divided at the 400 artefact mark for practical reasons. Studies smaller than 400 artefacts are mapped within 20-artefact bands, 
beginning with 1-20 artefacts (represented as ' 20 ' on the $\mathrm{x}$-axis), then $21-40$ artefacts, and so on. After the 381-400 artefact bracket (represented as ' 400 ' on the $x$-axis), the studies are shown in 200 -artefact bands in order to incorporate the few very large studies. The indication ' 600 ' on the $\mathrm{x}$-axis therefore represents the 401-600 artefact bracket, and so on up to 2601-2800 artefacts. Figure 2 breaks down the dominant ' $1-20$ artefact' category to reveal the emphasis on samples of three artefacts or fewer.

In addition to reviewing sample sizes by individual study, it is also beneficial to consider trends over time. In the following it should be stressed that phrases such as 'artefacts analysed per year' are used interchangeably with 'artefacts published per year', as it is rarely possible

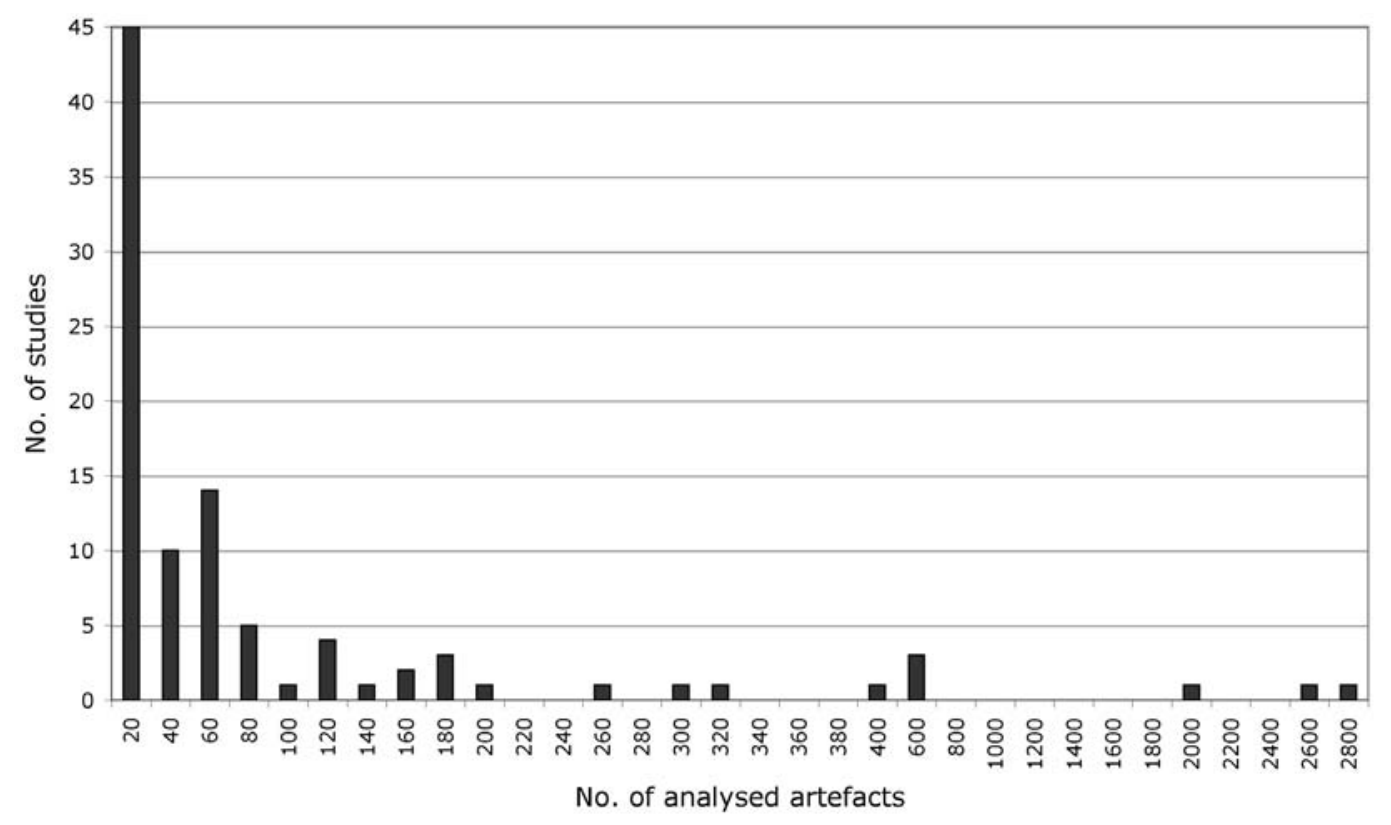

Figure 1. Number of stone artefacts analysed per stone-tool microscopic residue study, 19762006.

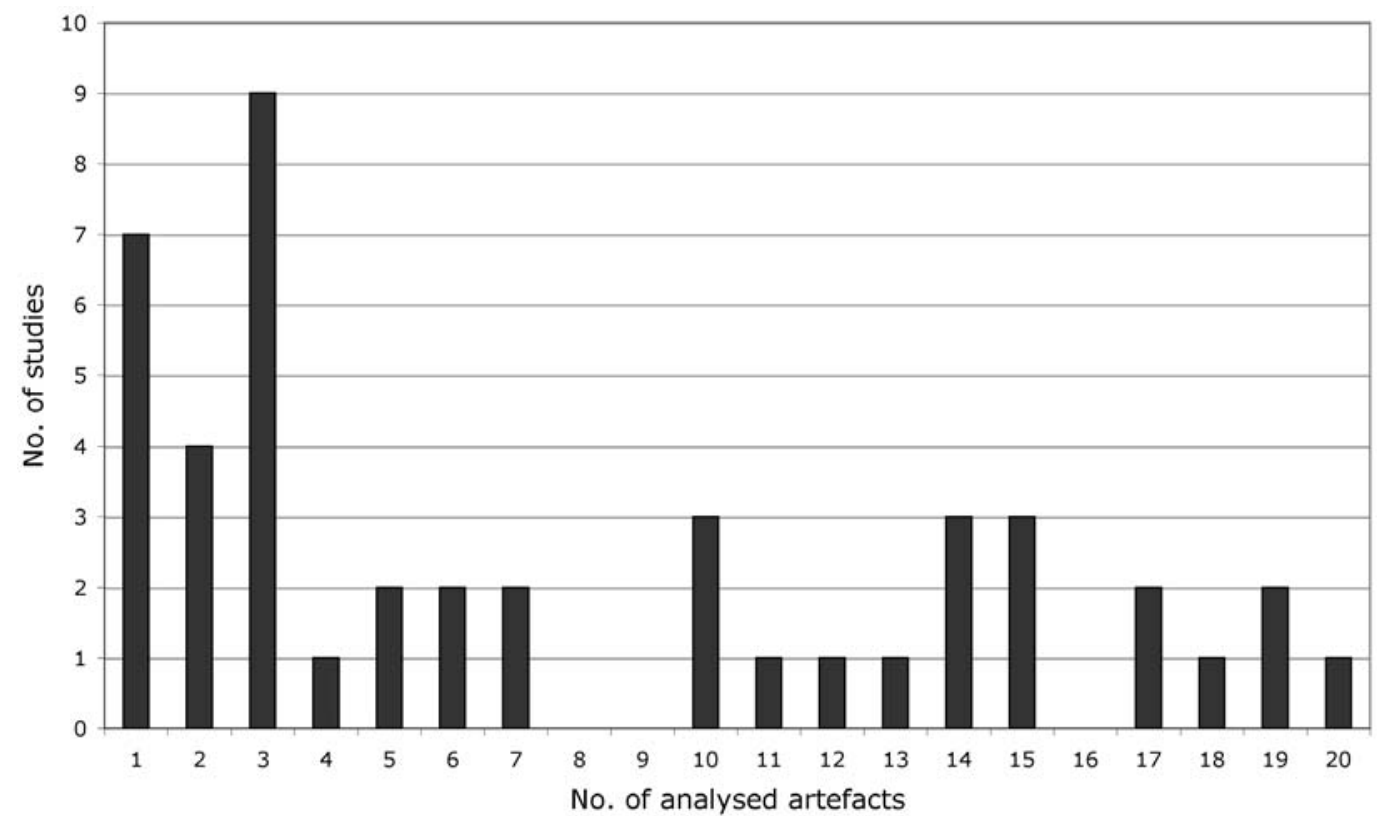

Figure 2. Number of stone artefacts analysed per microscopic residue study, 1976-2006 (120 artefact sample sizes only). 
to differentiate year of analysis from year of publication. The issues considered here, then, include the number of publications per year reporting original stone-tool microscopic residue results (Figure 3), the cumulative number of authors contributing to these publications (Figure 4 ), the number of artefacts examined per year worldwide (Figure 5), and the median sample sizes for analyses published each year (Figure 6). The former two graphs support the contention that the field is expanding and, while not all the authors included in Figure 4 are themselves residue analysts, this trend does show the rapidly increasing number of archaeologists willing to incorporate microscopic residue data into their work. Figure 4 is conservative in that publications discussing residues but not presenting new data are not included in the surveyed literature for this paper; however trends toward multiple authorship counter this conservatism somewhat.

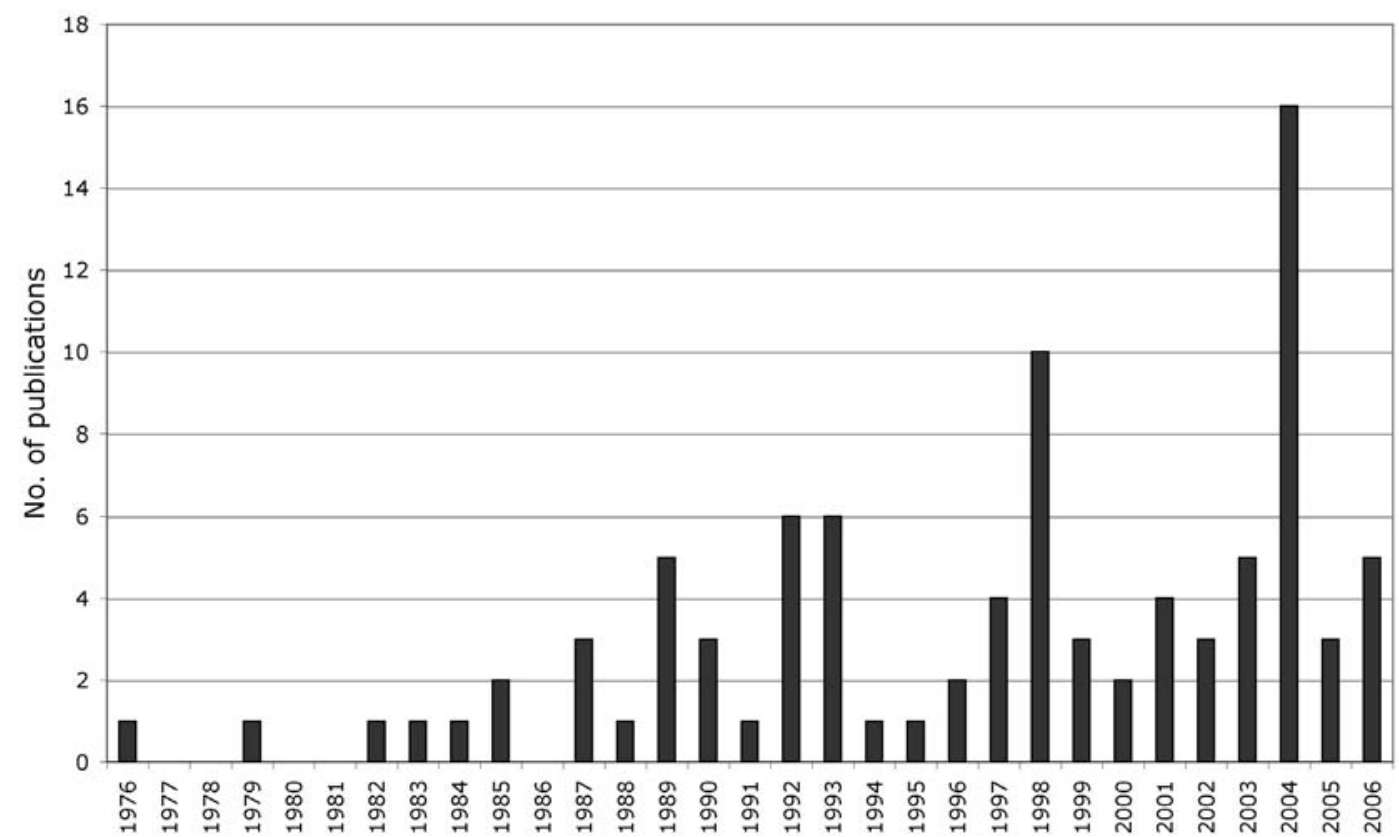

Figure 3. Number of publications reporting original results of microscopic stone-tool residue analyses per year, 1976-2006.

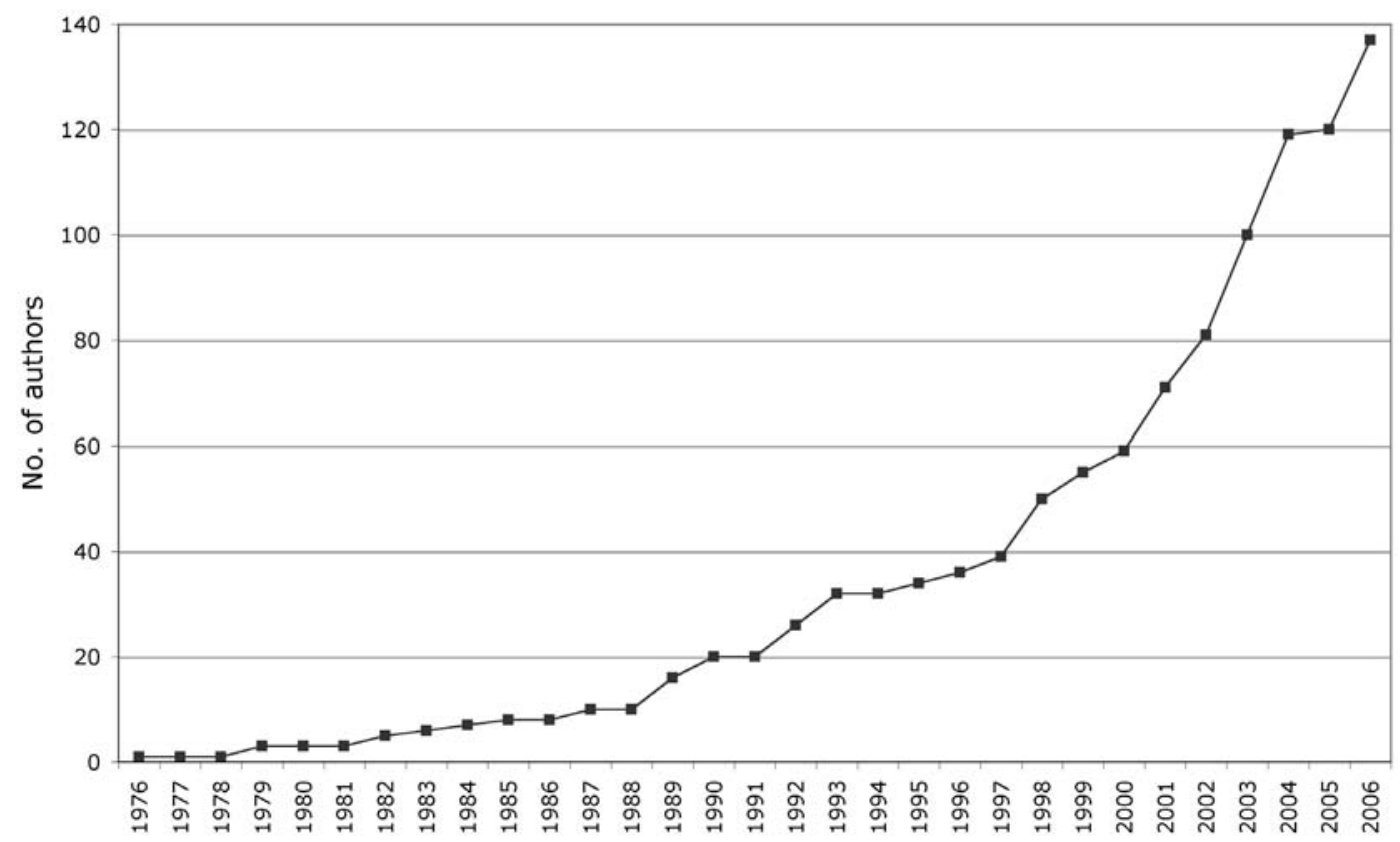

Figure 4. Cumulative total number of authors who have published original microscopic stone-tool residue results, 1976-2006. 


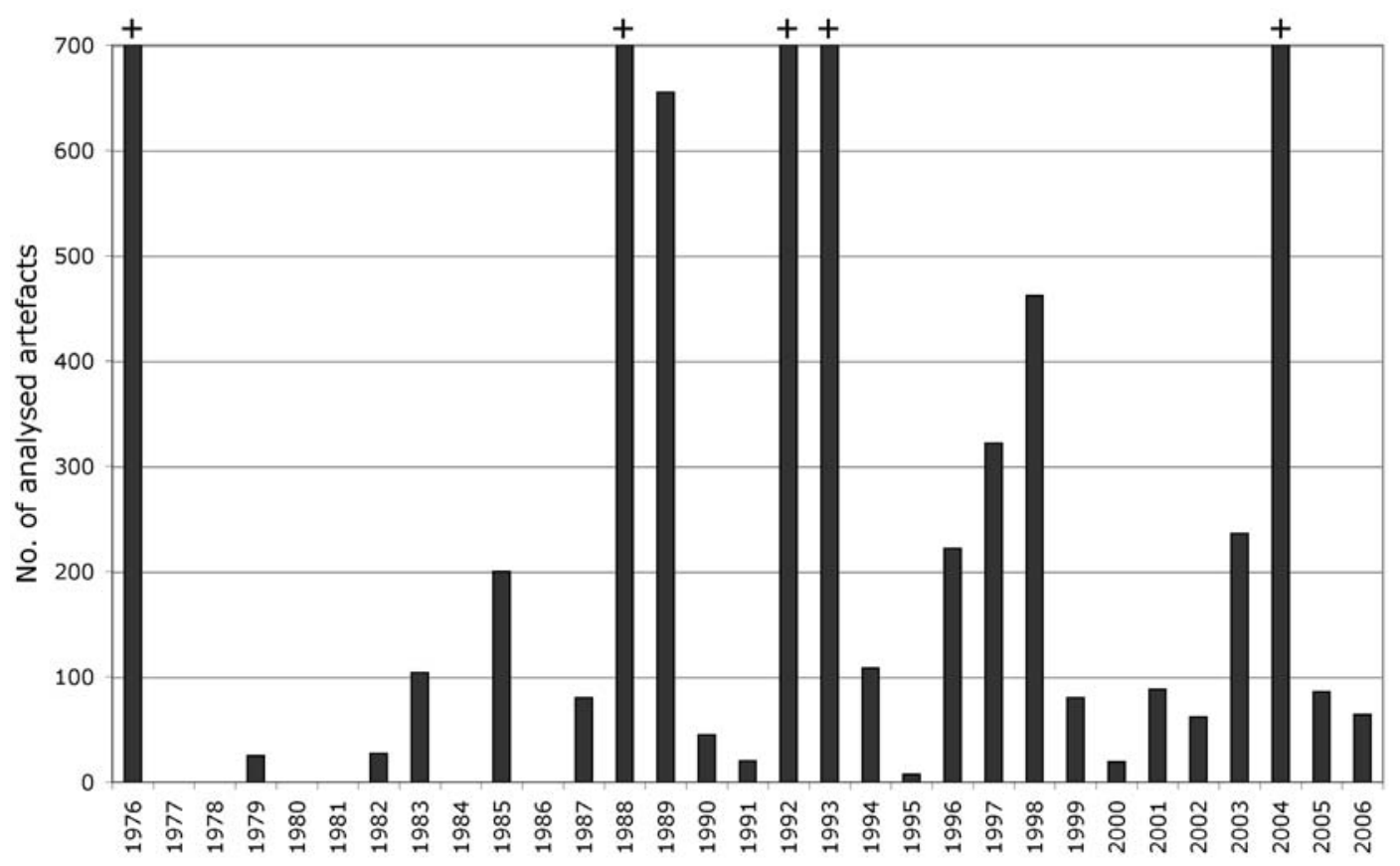

Figure 5. Number of stone artefacts analysed for microscopic residues per year, 1976-2006. Years marked with ' + ' have values beyond the range of the graph $(1976 n=2551 ; 1988$ $n=1814 ; 1992 n=1263 ; 1993 n=2798 ; 2004 n=1687)$.

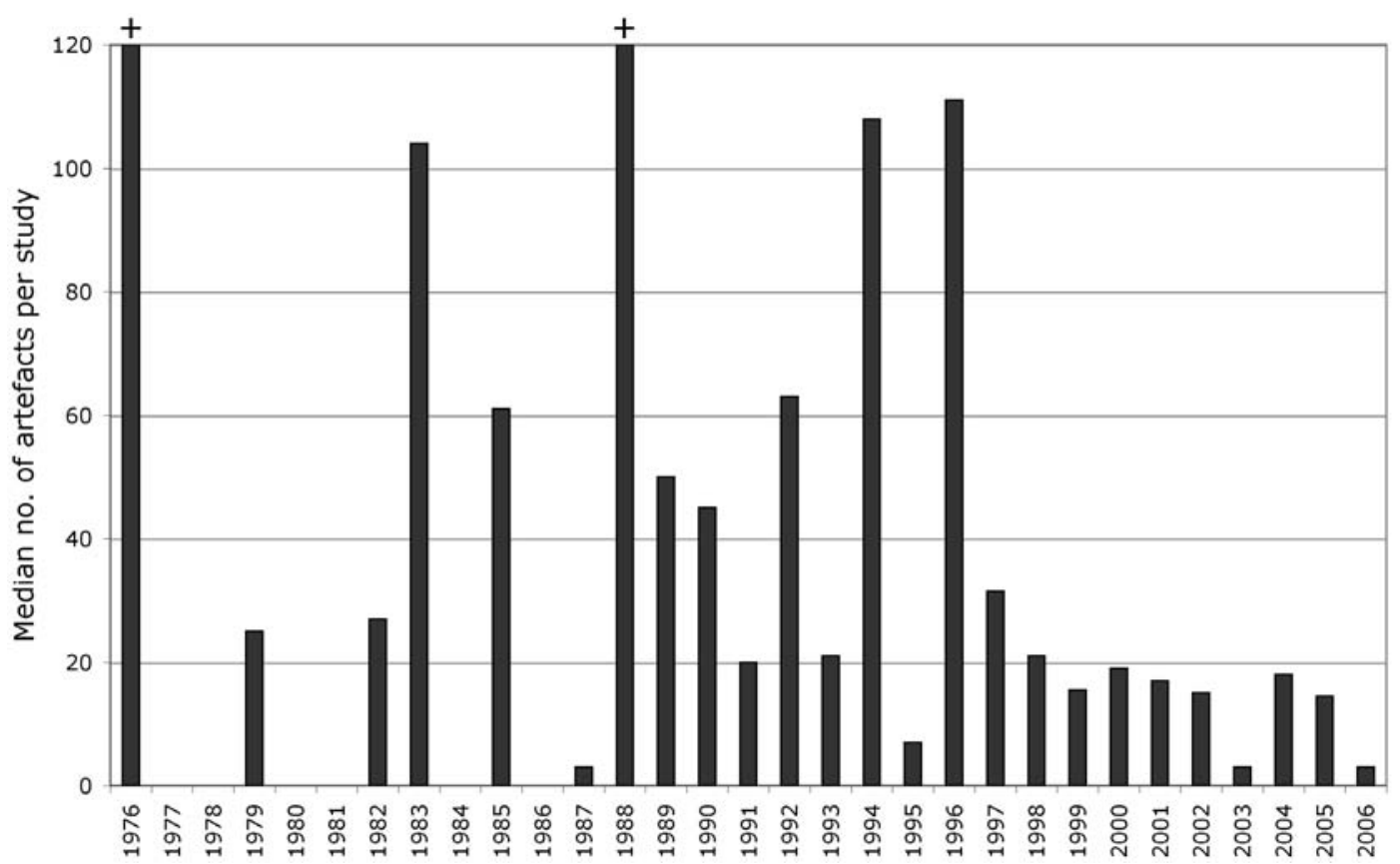

Figure 6. Median number of analysed artefacts per stone-tool microscopic residue study, 1976-2006. Years marked with ' + ' have values beyond the range of the graph $(1976 \mathrm{n}=\mathbf{2 5 5 1}$; $1988 \mathrm{n}=1814)$.

Figures 5 and 6 present two different perspectives on chronological quantification. Since 1976, five years have seen more than 700 artefacts analysed (Figure 5), largely attributable to the actions of individual researchers (Boot 1993; Briuer 1976; Fullagar 1988, 1992; Hardy 2004; and Williamson 2004, Wadley et al. 2004). Other than these exceptional occurrences, global residue research output is measured in the hundreds, and in many recent years the tens, of artefacts annually. There are however no striking trends in this highly variable data, even if a speculative 'pulse' of activity on a roughly five-year cycle is discerned over the past 20 years or so. Additionally, the 
figure for 2006 in this chart would be expected to increase with the inclusion of data from the latter part of that year. Figure 6 provides a valuable alternate viewpoint, displaying median annual sample sizes rather than means (which simply tend to follow a scaled-down version of the data in Figure 5) in an attempt to avoid the skew created by extreme outliers at the higher end of the scale. Two years (1976 and 1988) are again off the chart as they saw only one large published study each. Interestingly, once the field moved beyond its introductory phase and established itself in the late 1980s (the last year without at least one publication reporting an original set of light microscopy residue results was 1986; see Figure 3), there has been a slow and uneven but nevertheless relatively steady decline in median sample sizes. Note that unlike the totals in Figure 5, median values for the first half of 2006 are valid as they are independent of the number of studies. With only one exception, each year from 1988 to 1998 inclusive the median sample was above 20 artefacts per study; since 1998 the median has not exceeded this number. Importantly in this regard, 41 of the 91 publications (45\%) surveyed for this review were published since 1998, forming a significant component of the residue literature currently contributing to archaeological debate. Implications of declining sample sizes for archaeological interpretation are discussed further below.

A final approach to the data (Figures 7 and 8 ) is based on geography rather than sample size, and again illustrates the strong influence of a few individuals in the growth of the residue field. Microscopic stone-tool residue analyses have to date been completed by researchers working in a number of countries, however these may be divided into four broad geographic locations for the purposes of initial assessment - Oceania (principally Australia and Papua New Guinea), the Americas (especially North and Central America and northern South America), Africa (chiefly South Africa) and Eurasia. In reporting the numbers of artefacts analysed for each of these regions, I have broken the 30-year period since 1976 into five-year blocks (note that for the sake of inclusiveness the few studies from the first part of 2006 have been included in the final block). It is apparent from Figure 7 that initial application of microscopic residue analysis occurred in the Americas, and was followed subsequently by rapid growth in Oceania, and more recently South Africa. Studies of Eurasian material (with a focus on western Europe and the Middle East) have not seen the same expansion in terms of studied artefacts but have nonetheless continued steadily since their inception in the late 1980s.

As seen earlier the presence of large outlier studies is a strong influence and in this instance is directly related to the geographic focus of key analysts: Briuer initially in North America, Fullagar and Boot in Australia/Papua New Guinea, Hardy and Loy in Europe and Williamson in South Africa. It is worth noting in the context of this volume that Loy was responsible for training and/or early collaboration with many of these researchers, indicating the high impact (quantitatively and pedagogically) of individuals in shaping a field with relatively few practitioners. Interestingly, after 1990 a decline or plateau in numbers of analysed artefacts occurs in Oceania and the Americas alongside growth in Eurasia and Africa, despite increases in the numbers of studies published in all regions over the same period (Figure 8). A pattern of initial examination of large samples, perhaps as a form of method validation or training, followed by fragmentation into a variety of much smaller analyses is therefore apparent for the Americas, Oceania and to a lesser extent Eurasia. Whether this pattern will hold for Africa remains to be seen.

\section{REPRESENTATIVENESS AND STATISTICAL SIGNIFICANCE}

Having briefly considered the trends in typical sample sizes employed in stone-tool microscopic residue analysis, we may now consider the relevance of this information for archaeological interpretation. In general, for any project the impact of sample size on the inclusiveness or representativeness of results is dependent on the question asked, the target population, and the qualitative or quantitative nature of the enquiry. Piperno et al. (2004) for example examined a single grindstone, yet the provenance (Upper Palaeolithic Israel) and observed residues (starches indicative of barley processing) warranted publication in a prestigious scientific journal. There is no 


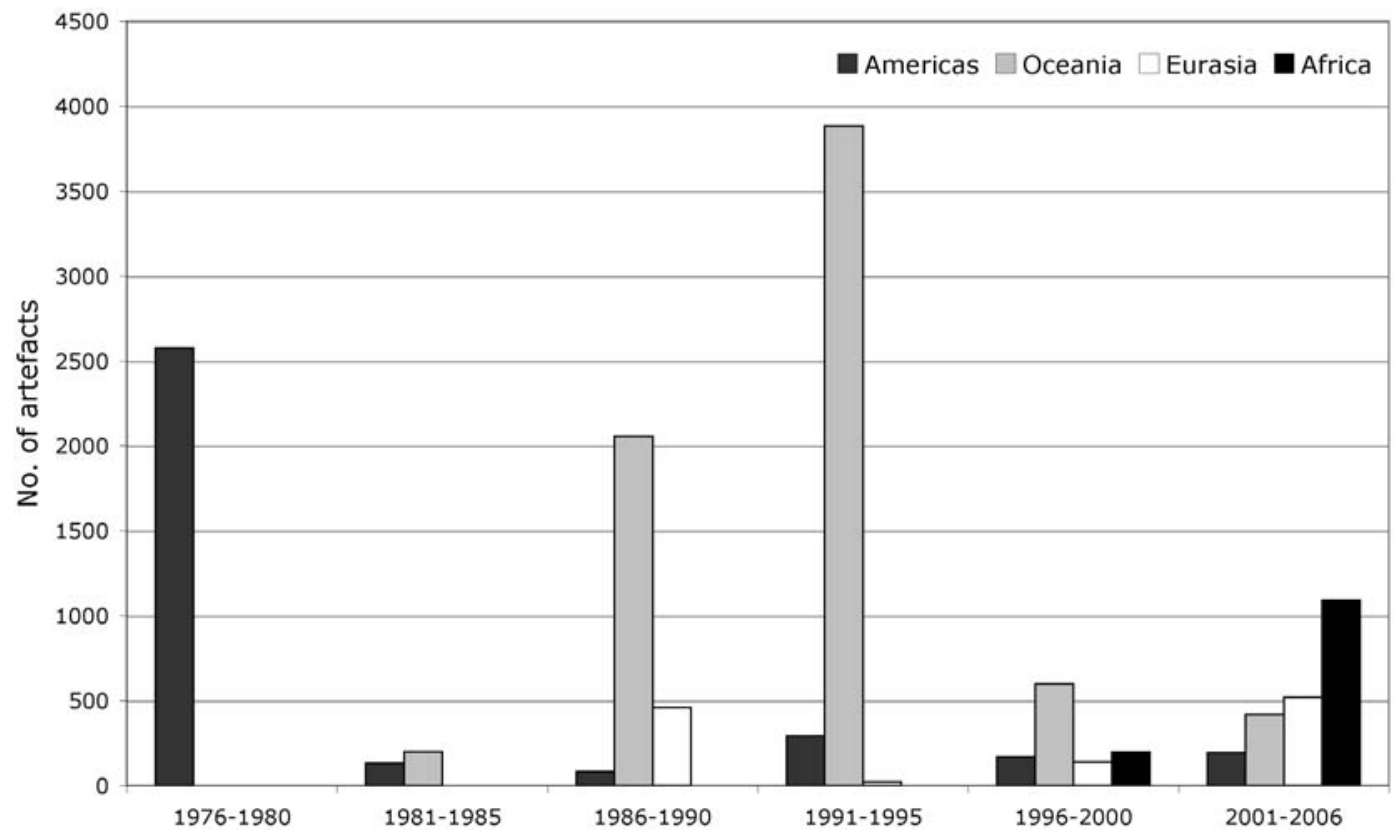

Figure 7. Number of stone artefacts analysed for microscopic residues per 5-year period, by geographic region.

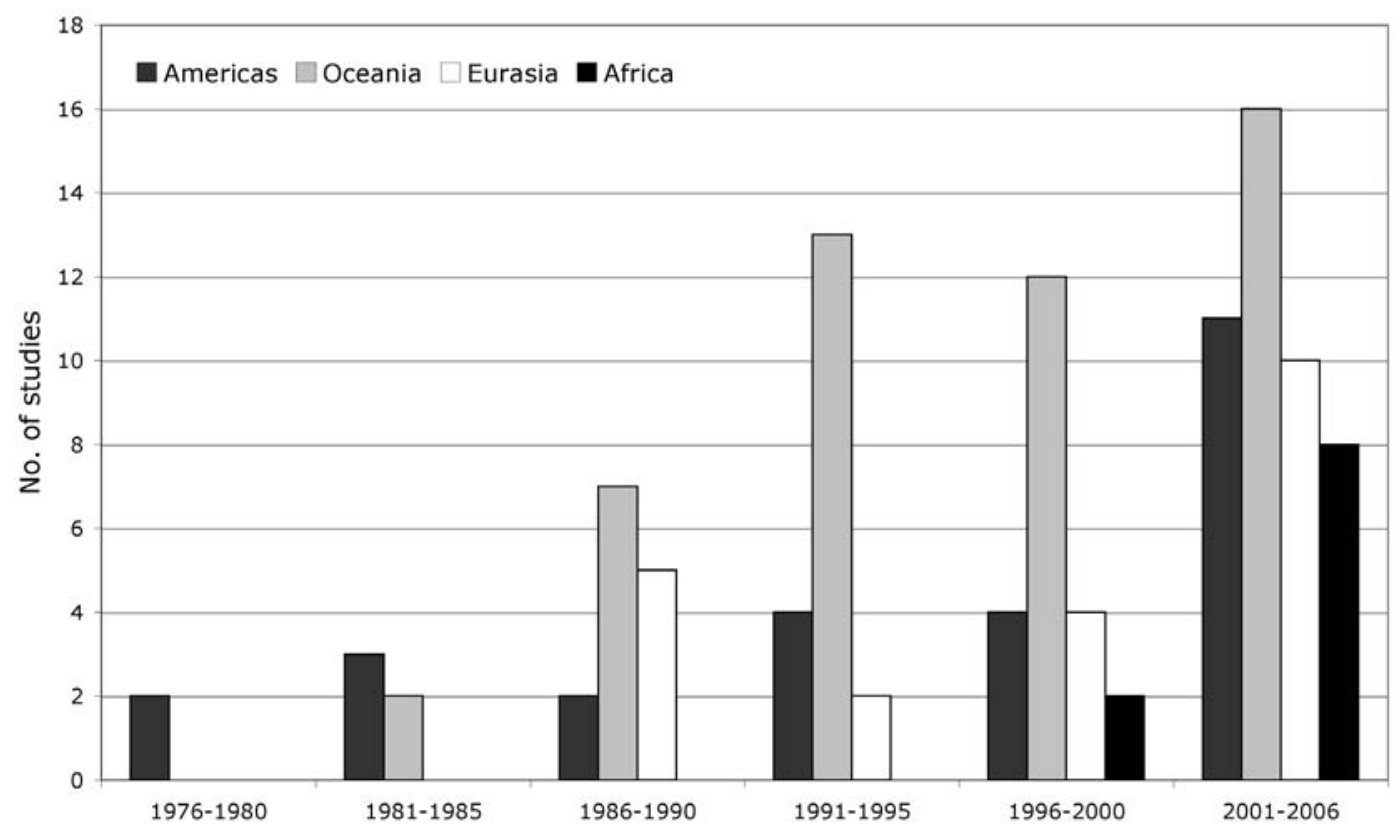

Figure 8. Number of published stone-tool microscopic residue studies per 5-year period, by geographic region.

need, and in fact it is somewhat counter-intuitive, to extrapolate the results of the earliest evidence for grass-seed processing to other sites or artefacts. The unspoken, but correct, assumption in this situation is that the implications for our understanding of past social organisation, dietary shifts and economic factors behind the use of a single artefact are profound enough to warrant publication. The routine residue analysis of non-descript artefacts that do not have a proxy importance gained through age, location or rarity may require justification in other terms, especially when choices are made as to which sites will be analysed and which cannot due to financial and time constraints. At the same time, it is usually the non-descript, 'everyday' artefacts that are most prevalent and available for study, even though these may appear essentially identical in potential information content from site to site in a given region. Factors other than perceived importance may also 
influence sampling decisions - for example artefacts of limited typological or display value may escape rigorous cleaning and therefore provide more appropriate candidates for residue study. The key is to ensure that the questions asked and the conclusions drawn are both relevant for the actual pieces of stone examined.

At the heart of the matter is a simple question: is it possible or meaningful to talk of a 'valid microscopic residue analysis sample size'? In this sense statistics may provide some guidance. The point at which a randomly selected sample from an unknown population size (the case for the vast majority of archaeological material) becomes statistically significant can be calculated for a number of confidence levels. The most common confidence level employed by archaeologists is $95 \%$, although at its base this is an arbitrary choice (Cowgill 1977). The data generated by residue analysts can be considered categorical (non-numerical), in that there is no justifiable basis yet established for treating, for example, the presence of 15 starch granules or collagen fibres on a used tool edge as being meaningfully different to finding 12 or 30 granules or fibres on that edge, thanks largely to taphonomic factors. In addition, as studies often report the proportions of various residue types and inferred uses of analysed artefacts (e.g. Fullagar 1992; Lombard 2008), the following equation can be used to calculate the number of artefacts that must be examined to make statements of statistical significance for a particular confidence level (Drennan 1996):

$$
\mathrm{n}=\left(\frac{\sigma \mathrm{t}}{\mathrm{ER}}\right)^{2}
$$

where $\mathrm{n}=$ the required sample size.

$\sigma=$ the standard deviation of the sample.

$\mathrm{t}=$ the Student's $\mathrm{t}$ distribution value for the desired confidence level.

$\mathrm{ER}=$ the error range (or confidence interval) for the sample.

Using proportional data, the standard deviation is found by:

$$
\sigma=s=\sqrt{p q}
$$

where $\mathrm{p}=$ the proportion of artefacts expressed as a decimal fraction; $\mathrm{q}=1-\mathrm{p}$.

If the proportions of artefacts used for various tasks are unknown to begin with (again typical in residue studies) then the most conservative guess of 50\% can be used (Drennan 1996:143). This guess means that if there is any variation from $50 \%$, the resulting error ranges will be smaller than those calculated - in other words the result will only become more precise. This information can be used to calculate the number of artefacts that must be examined to make a statistically valid statement about the inferred tasks represented by those artefacts. Using the $t$ value (1.96) associated with the standard $95 \%$ confidence level for a large unknown population size, an error range of $\pm 5 \%$, and a proportion of $50 \%$, then:

$$
\sigma=\sqrt{p q}=\sqrt{(0.5)(1-0.5)}=0.5
$$

and

$$
\mathrm{n}=\left(\frac{(0.5)(1.96)}{0.05}\right)^{2}=384.16
$$

To summarise, an analyst is required to examine 385 artefacts randomly selected from a given context to be able to speculate on the representativeness of their (categorically-described) residue 
findings for that context at a $95 \%$ confidence level. Of the 91 studies listing sample sizes in the Appendix, only eight exceed this figure. If an analyst wishes to divide their sample, for example into different temporal periods or spatial areas, each of those divisions would require 385 artefacts to make assertions at this confidence level, provided of course that the requisite number of artefacts were recovered. As a point of comparison, 25 of the studies in the Appendix analysed sufficient artefacts to assert statistical significance at the $90 \%$ confidence level (requiring 68 artefacts with a $\pm 10 \%$ error range), and 66 had a sufficient sample to assert statistical significance at the $80 \%$ confidence level (requiring 11 artefacts with a $\pm 20 \%$ error range). None of these studies contain statistical calculations of significance for the findings they report. In fairness, while heuristically valuable, confidence levels are not fixed boundaries that decisively assign a given study into a box labelled either 'true' or 'false' (Ringrose 1993), and as noted even one artefact may supply a wealth of information. The important point is for residue analysts to apply appropriate statistical reasoning, at appropriate times, to support and strengthen their conclusions.

The misuse of or blind faith in statistical analyses has been identified by Cowgill (1993:552553 ) as one of the major shortcomings of archaeological processualism, while at the same time commenting that 'Quantitative techniques can be treated lightly only if one believes that remains of the past themselves have little bearing on our judgements about the merits of different stories'. To muddy the statistical waters further, there is also no necessary correlation between the number of artefacts analysed in a given study and the number with identifiable and interpretable residues. For example, Briuer's (1976) analysis, the first reported stone-tool microscopic residue study and still the second largest, found identifiable organic use residues on 37 (or 1.5\%) of 2551 analysed flakes. With residue studies in their infancy, however, Briuer may have missed or been unable to identify residues that would now be routinely recorded. The largest reported study to date (Boot 1993) found 165 hafting or use residues on 2722 artefacts (6\%); the third largest (Fullagar 1988 ) found residues on 13 of 1814 artefacts $(0.7 \%)$. Much higher rates have been reported from other studies, including the early work of Loy (1983) who reported blood residues on 90 of 104 artefacts (87\%). These results demonstrate that there is no sure ratio of analysed artefacts to artefacts with residues, a fact that may be intuitive but could cause problems if attempts at quantitative comparisons are made. These problems are compounded by variations in sampling rationale: artefacts for residue studies have been drawn randomly from the available assemblage (e.g. Haslam 2003); chosen selectively by the archaeologist as likely to have been used (e.g. Veth et al. 1997); chosen to cover a range of temporal periods and raw materials (e.g. Barton 1990); or the sample is the complete assemblage from a pit or site (e.g. Fullagar and David 1997). Attempting to compare inter-study percentage results of, for example, plant and animal processing tools (e.g. Boot 1999) may be inappropriate in light of these diverse sampling procedures.

The restrictions that small sample sizes impose on the broader applicability of results were recognised early on by Shafer and Holloway (1979:398), who noted that for their sample of 25 artefacts they 'fully realize the limited application of the overall findings regarding the use of tools in the assemblages being studied'. Fullagar (1987:26) likewise observed that in determining overall site function, 'for sites with very small numbers of tools, the proportion of materials worked may be meaningless', a sentiment which has obvious correlation with analyses of small samples, regardless of the assemblage size from which they are drawn. The majority of studies in the Appendix make no mention of a carefully reasoned sampling strategy based on a welldefined target population, which is either an omission in reporting protocols or evidence that the impact of sampling on the relevance and reliability of results has to this point largely been overlooked. It is also possible that the lack of explicit published sampling rationales correlates with indications that many stone-tool microscopic residue analyses may begin with an aim of simply 'finding out what's there' (Haslam 2006b), and only subsequently are the results broadened into discussions of, for example, regional subsistence practices (see Hardy and Svoboda [this volume] for an alternative to this scenario). The desirability of examining entire assemblages to produce defensible results was highlighted recently by Smith (2004:174) in a study of starch on grindstones, although the logistics of such a task often may be prohibitive. As microscopic residue 
analyses have increasingly taken a central role in key world archaeological debates, especially concerning early plant domestication and food processing (Denham, et al. 2003; Fullagar and Field 1997; Fullagar, et al. 2006; Perry, et al. 2006; Piperno, et al. 2000; Piperno, et al. 2004), it is likely that sampling issues will play a correspondingly important role in further progressing the value of the field.

\section{TARGETS AND SAMPLES, MOUNTAINS AND MOLEHILLS}

Microscopic stone-tool residue analysis is time-consuming and expensive, and with current median values of less than 20 artefacts per study, there are clearly benefits in openly discussing the kinds of questions we want microscopic residues to address. If total-assemblage projects were to become the norm, then there would be few restrictions on research targets - everything from broad studies of non-lithic artefact production, prehension and cognitive processes to classification of artefacts by use rather than form (and much more) would be worth exploring. In the shortterm, however, more may be gained from questions that maximise the value of small samples, and selectively target larger numbers of artefacts when required. For example, in recent years researchers in the Americas in particular (e.g. Perry et al. 2006) have established a solid research agenda concentrated on the variety of human-plant interaction, plant processing and settlement information to be gained from focused studies of starch residues, with an emphasis on ground stone artefacts. Alternatively, for non-descript stone pieces we may profitably consider the social roles of individual artefacts (Haslam 2006a; Haslam and Liston 2008). This approach relies on contextual data for one or a few artefacts (demonstrated above to be the most commonly analysed sample sizes) as an alternative to extrapolating results over a site or region. Recent investigations of South African hafting and hunting technologies (e.g. Gibson et al. 2004; Lombard 2005; Wadley et al. 2004) also demonstrate the interpretive value of a clear research focus, building a broad perspective from successive related studies.

Perhaps the most obvious way to bring sampling into a more prominent position within residue analysis is to re-examine existing studies, first determining the scale (target population) of the presented discussion, then comparing this with the quantity and contexts of the analysed artefacts. This task would take more space than is available here and is by no means straightforward; as a start however, questions arising from a few brief examples may be considered to introduce the concept. Consider first the recent work of Dominguez-Rodrigo et al. (2001) on East African Acheulian handaxes, a significant study reporting the oldest microscopic use-residues to date and rigorously documenting clear associations between tools and their residues over a very large time period. From a sampling perspective, then, we may begin by asking how many Acheulian handaxes need to be analysed before any generalisations about early human use of these tools can be made? Are the three analysed by Dominguez-Rodrigo et al. (2001:292), from one site dated to 1.4-1.7 million years ago, sufficient? What about thirty or three hundred, and across how many sites? The authors identified traces of woodworking residues on two of the three handaxes; to what extent can this finding be interpreted as showing 'that humans, at a very early stage of their evolution, were producing wooden implements' (Dominguez-Rodrigo et al. 2001:297-298), with implications for complex hominid intelligence? In broader contextual perspective, what role should wooden spears from Germany or England made more than one million years later have in strengthening hypotheses about early East African handaxe use for spear-making (DominguezRodrigo et al. 2001:289, 298)?

A discussion of potential handaxe use for the continents and hundreds of millennia across which these artefacts are found is well beyond the scope of this paper, and the requisite functional analyses of representative samples from well-dated Acheulian assemblages divided into different environmental, geographical, hypothesised site-function and temporal zones is non-existent. Nevertheless, given the large numbers of handaxes currently in museum collections and a long history of functional speculation and investigation (e.g. Keeley and Toth 1981; Kohn and Mithen 1999; Shick and Toth 1993; Whittaker and McCall 2001) this artefact type would appear to be 
an ideal target for a series of residue studies aimed at determining both basic population-wide use-data and the role of sampling in potentially biasing interpretations. We may ask, for example, if the proportion of plant to animal working tools seen in a given study varies independently of sample size, or is asymptotic for larger samples? Are there site- or region-specific patterns suggesting environmental and/or social influences on use? Were these artefacts even made for use as tools (Davidson 2002)? Dominguez-Rodrigo et al. have commendably established a necessary base-line for beginning to address such questions, but well-defined target populations are clearly required before broadening results beyond the site and time period examined.

Sampling concerns do not only affect such spatiotemporally vast constructs as the Acheulian, of course, and with this in mind we may examine a second important recent study. Perry (2005) successfully gathered both botanical and artefact functional data from starch analysis of five microlithic 'manioc' grater flakes from a Venezuelan site, providing excellent contextual information for the location some 1200-1500 years ago and demonstrating the range of activities for which these particular tools were employed. At the same time, Perry (2005:414) uses the results to evaluate 'the validity of the direct historical approach in the interpretation of archaeological artifacts from the middle Orinoco valley' by comparing the ethnographically-derived assumption of manioc grating to the actual tool functions observed microscopically. Again from a sampling perspective, the question at hand is whether the reported starch analysis of five artefacts, from one half of one level of a $1 \mathrm{~m} \mathrm{x} 1 \mathrm{~m}$ test unit at one site, is sufficient for such an evaluation.

The Orinoco case study has relevance for all functional projects that attempt to test ethnographically-derived functional assumptions, and as the stated target is in this instance quite broad the sample ideally should be equally comprehensive. It is likely therefore that artefacts from a number of sites in the middle Orinoco and across a number of time periods leading up to the ethnographic present would require examination to judge the validity of the direct historical approach in this region. In the absence of such data it is difficult to judge the representativeness of the analysed pieces for the middle Orinoco assemblage. As a test, it seems reasonable to assume that a representative sample suitable for addressing the target question would be able to aid in identifying the point at which direct historical approach becomes valid, that is, when ethnographically-observed activities become the dominant ones for these microliths. The sample selected does not permit such an assessment. Perry has certainly demonstrated the inapplicability of the direct historical approach to interpreting her sample of five artefacts, and the extrapolation from this to the whole middle Orinoco may appear a minor one, but it is precisely the feasibility of such extrapolations that sampling designs make explicit. Tangentially, it could be asked whether narrowing the study's discussion solely to statements relevant to the analysed artefacts and their immediate context may diminish its value, and therefore restrict the potential publishing venues. In other words, there is a tension between on the one hand the restrictions imposed in microscopic residue analysis by a time-consuming practical component, and on the other a requirement to make the results as useful to others as possible.

In these examples a case may be argued for both large and small-scale interpretation of limited sample studies, depending on the reader's willingness to follow the author's leap from sample to target. Similar issues, including extrapolation from single site analyses to regional patterns, and from precise reconstruction of limited individual tool use to broad generalisations about short or long term human activities are worth discussing for many of the studies conducted to date. That said, all projects progress sequentially over time, and small sample sizes addressing questions aimed at small, well-defined target populations are entirely valid. The key point is that archaeologists engaged in microscopic stone-tool residue studies have not been as stringent in our identification of target populations as we could be, and explicit demonstrations of how sampling strategies (of however many artefacts) tie back to a given target are often conspicuously absent. In a related issue facing all archaeologists, we may ask whether the use of qualifier terms such as 'preliminary', or phrases such as 'hints at' or 'suggests' rather than 'demonstrates', justify making claims beyond the significance warranted by the sample size? Use of such terms may be tempting, particularly in a field such as microscopic residue analysis where time and financial constraints 
act to restrict the number of artefacts that may be examined, while as in any field publication pressures demand a high level of impact for the results. Equally important is the fact that residue analyses often produce striking results of specific tool-use that are likely to excite the imagination, perhaps contributing to an overstatement of significance. If care is not taken, however, results first reported as preliminary or speculative may after repetition come to be cited as reliable facts. Overall, the contribution of sampling theory to such issues is, as Orton (2000:206) points out, 'in providing a language and a frame of reference within which such problems can be discussed, rather than definitive answers'.

What then are the prospects for augmenting current practices that emphasise many studies of few artefacts rather than vice versa? Apart from a need to improve the reporting of sampling strategies and to explicitly tie the scale of conclusions to the scale of analysis, several additional options are available. First, as mentioned earlier, a theoretical turn towards highly contextualised interpretation of individual actions offers an alternate path for residue results from a limited number of artefacts (Haslam 2006a). This approach is designed to provide a humanised and agent-centred past as a further line of investigation complementary to current research agenda, rather than to directly address the 'big picture' questions of archaeology, and it therefore provides a potentially valuable but only partial solution. A second approach is to conduct a series of dove-tailed research projects at the one site or region, which may then by accretion answer questions at successively larger theoretical and geographical scales. Excellent examples of this approach include Fullagar's work in West New Britain, Williamson and more recently Lombard's studies of Rose Cottage Cave and Sibudu Cave in South Africa, and Hardy's work in Crimea.

One of the chief benefits of such long-term investment in particular sites and regions is that additional small-sample research may be justifiably incorporated into an established framework. Researchers working on well-studied sites, especially where lithic technological information is also available, are in the best position to identify relevant large-scale issues with which residue analysis may engage. The contributions to this volume by each of the researchers mentioned demonstrate that the necessary vitality exists in the field to generate productive discourse on this issue. As a natural corollary to this last point, where discussions of broad trends are a desired outcome then initiation of further projects that aim from the outset to examine significant proportions of a site or regional assemblage will be essential. And finally, a third path for increasing the scale of analyses without incurring significantly greater costs is to conduct initial rapid screening of artefact assemblages for residue-bearing artefacts. Subsequent sample selection from among those artefacts with clear residues avoids some of the problems noted earlier but introduces new challenges for relating the residue-bearing assemblage to the lithic assemblage and target population as a whole.

\section{CONCLUSION}

With a trend over the past decade toward smaller sample sizes, and typical samples measured in the tens of artefacts or less, sampling theory suggests that analysts should be implementing an accompanying constriction in the scale of conclusions drawn from microscopic stone-tool residues. In practice, such constrictions may be alleviated or overcome through explicit recognition of the limitations built into small-scale analyses. In this regard it would be insufficient, for example, to label a study 'preliminary' and then to disregard this fact in either the conclusions of that same study or in future publications. In comparison with lithic technological research in which many thousands of artefacts or complete assemblages are routinely recorded for a given site, it is perhaps surprising that microscopic lithic residue analyses have yet to come under greater scrutiny for their sampling practices, and in this regard the success of the technique may obscure its limitations somewhat. There are logistical impediments to the widespread use of a whole-assemblage approach to residues, however it is only through such projects that we gain the necessary baseline data against which the reliability of small-sample conclusions can be evaluated. Caution in interpreting small-sample studies and an explicit focus on the relative 
merits of different sample sizes can only result in greater explanatory power and wider acceptance and integration for all microscopic stone-tool residue analyses.

\section{ACKNOWLEDGEMENTS}

Throughout this paper I have referred to 'Loy', as academic convention dictates. To me he will however always be Tom, an inspiring mentor and excellent storyteller. My thanks go to Tom for introducing me to residues, and to my fellow archaeologists over the years in the Archaeological Science Laboratory and School of Social Science at the University of Queensland for their encouragement. Thanks also to the growing band of microscopic residue analysts who make a review like this one possible, and who are slowly but surely changing the way we see the past. Valuable constructive comments and support were received from Richard Fullagar, Gail Robertson and Chris Clarkson. Parts of this paper were presented in the UQ Working Papers in Archaeology seminar series in March 2007. Thank you to everyone who provided feedback on that occasion. Portions of the research contained in this paper were funded by an Australian Postgraduate Award.

\section{REFERENCES}

Akerman, K., R. Fullagar and A. van Gijn 2002. Weapons and wunan: production, function and exchange of Kimberley points. Australian Aboriginal Studies 2002/1:13-42.

Anderson, P. 1980. A testimony of prehistoric tasks: diagnostic residues on stone tool working edges. World Archaeology 12(2):181-193.

Anderson, P., J. Chabot and A. van Gijn 2004. The functional riddle of 'glossy' Canaanean blades and the Near Eastern threshing sledge. Journal of Mediterranean Archaeology 17(1):87130.

Anderson-Gerfaud, P. 1990. Aspects of behaviour in the Middle Palaeolithic: functional analysis of stone tools from southwest France. In P. Mellars (ed.) The Emergence of Modern Humans: An archaeological perspective, pp. 389-418. New York: Cornell University Press, Ithaca.

Atchison, J. and R. Fullagar 1998. Starch residues on pounding implements from Jinmium rockshelter. In R. Fullagar (ed.) A Closer Look: Recent Australian studies of stone tools, pp. 109-125. Sydney: Archaeological Computing Laboratory, University of Sydney.

Attenbrow, V., R. Fullagar and C. Szpak 1998. Stone files and shell fish-hooks in southeastern Australia. In R. Fullagar (ed.) A Closer Look: Recent Australian studies of stone tools, pp. 127-148. Sydney: Archaeological Computing Laboratory, University of Sydney.

Babot, M. d. P. 2001. La molienda de vegetales almidonosos en el noroeste Argentino prehispanico. Publicatcion Especial de la Asociacion Paleontologica Argentina 8:59-60.

Babot, M. d. P. and M.C. Apella 2003. Maize and bone: residues of grinding in Northwestern Argentina. Archaeometry 45(1):121-132.

Balme, J., G. Garbin and R.A. Gould 2001. Residue analysis and palaeodiet in arid Australia. Australian Archaeology 53:1-6.

Barton, H. 1990. Raw Material and Tool Function: A residue and use-wear analysis of artefacts from a Melanesian rockshelter. Unpublished BA (Hons) thesis. Sydney: University of Sydney. 
Barton, H., R. Torrence and R. Fullagar 1998. Clues to stone tool function re-examined: comparing starch grain frequencies on used and unused obsidian artefacts. Journal of Archaeological Science 25:1231-1238.

Barton, H. and J.P. White 1993. Use of stone and shell artefacts at Balof 2, New Ireland, Papua New Guinea. Asian Perspectives 32(2):169-181.

Baxter, M. 2003. Statistics in Archaeology. Arnold, London.

Boot, P.G. 1993. Analysis of resins and other plant residues on stone artefacts from Graman, New South Wales. In B.L. Fankhauser and J.R. Bird (eds) Archaeometry: Current Australasian Research, pp. 3-12. Occasional Papers in Prehistory, No. 22. Canberra: Department of Prehistory, Research School of Pacific Studies, The Australian National University.

Boot, P.G. 1999. Preservation of use related residues on stone artefacts from Graman. In by M.-J. Mountain and D. Bowdery (eds) Taphonomy: The analysis of processes from phytoliths to megafauna, pp. 35-40. Canberra: ANH Publications.

Brass, L. 1998. Modern stone tool use as a guide to prehistory in the New Guinea Highlands. In R. Fullagar (ed.) A Closer Look: Recent Australian studies of stone tools, pp. 19-28. Sydney: Archaeological Computing Laboratory, University of Sydney.

Briuer, F. L. 1976. New clues to stone tool function: plant and animal residues. American Antiquity 41(4):478-484.

Broderick, M. 1982. Residue analysis of artifacts and flakes recovered from the Telep Site DhRp 35. Appendix 2. In W.R.B. Peacock (ed.) The Telep Site: A late autumn fish camp of the Locarno Beach Culture type. Unpublished report on file, Heritage Conservation Branch, Victoria, British Columbia, Canada.

Cattaneo, C., K. Gelsthorpe, P. Phillips and R. J. Sokol 1993. Blood residues on stone tools: indoor and outdoor experiments. World Archaeology 25(1):29-43.

Chandler-Ezell, K., D. Pearsall and J. A. Zeidler 2006. Root and tuber phytoliths and starch grains document manioc (Manihot esculenta), arrowroot (Maranta arundinacea), and Lleren (Calathea sp.) at the Real Alto site, Ecuador. Economic Botany 60(2):103-120.

Cosgrove, R. 1985. New evidence for early Holocene aboriginal occupation in northeast Tasmania. Australian Archaeology 21:19-36.

Coughlin, E. and C. Claassen 1982. Siliceous and microfossil residues on stone tools: a new methodology for identification and analysis. In R.M. Gramly (ed.) The Vail Site: A PalaeoIndian encampment in Maine. Buffalo, NY: Bulletin of the Buffalo Society of Natural Sciences.

Cowgill, G.L. 1977. The trouble with significance tests and what we can do about it. American Antiquity 42(3):350-368.

Cowgill, G.L. 1993. Distinguished Lecture in Archeology: beyond criticizing New Archeology. American Anthropologist 95(3):551-573.

Davidson, I. 2002. The finished artefact fallacy: Acheulean hand-axes and language origins. In A. Wray (ed.) The Transition to Language, pp. 180-203. Oxford: Oxford University Press.

Davis, K. 1999. Preliminary analysis of starch residues on ground stone tools from Mleiha. In M. Mouton (ed.) Mleiha, Vol. 1: Environnement, Stratégies de Subsistance et Artisanats, pp. 89-96. Lyon: Maison de 1’Orient méditerranéen. 
Denham, T.P., S.G. Haberle, C. Lentfer, R. Fullagar, J. Field, M. Therin, N. Porch and B. Winsborough 2003. Origins of agriculture at Kuk Swamp in the Highlands of New Guinea. Science 301:189-193.

Denham, T.P. and H. Barton 2006. The emergence of agriculture in New Guinea: a model of continuity from pre-existing foraging practices. In D.J. Kennett and B. Winterhalder (eds) Behavioral Ecology and the Transition to Agriculture, pp. 237-264. Berkeley: University of California Press.

Dodson, J., R. Fullagar, J. Furby, R. Jones and I. Prosser 1993. Humans and megafauna in a late Pleistocene environment from Cuddie Springs, north western New South Wales. Archaeology in Oceania 28:94-99.

Dominguez-Rodrigo, M., J. Serralonga, J. Juan-Tresserras, L. Alcala and L. Luque 2001. Woodworking activities by early humans: a plant residue analysis on Acheulian stone tools from Peninj (Tanzania). Journal of Human Evolution 40:289-299.

Downs, E.F. and J.M. Lowenstein 1995. Identification of archaeological blood proteins: a cautionary note. Journal of Archaeological Science 22:11-16.

Drennan, R.D. 1996. Statistics for Archaeologists: A commonsense approach. New York: Plenum Press.

Frederickson, C. 1985. The detection of blood on prehistoric flake tools. New Zealand Archaeological Association Newsletter 28(3):155-164.

Fullagar, R. 1982. What's the Use? An analysis of Aire Shelter II, Glenaire, Victoria. Unpublished MA (Prelim) thesis. La Trobe University.

Fullagar, R. 1987. Use-wear and residue analysis of Birrigai stone artefacts. In J. Flood, B. David, J. Magee and B. English, Birrigai: a Pleistocene site in the south-eastern highlands. Archaeology in Oceania 22(1):25-26.

Fullagar, R. 1988. Recent developments in Australian use-wear and residue studies. In S. Beyries (ed.) Industries Lithique: Traceologie et technologie, pp. 133-145. British Archaeological Reports International Series 411.

Fullagar, R. 1989. The potential of lithic use-wear and residue studies for determining stone tool functions. In P. Gorecki and D. Gillieson (ed.) A Crack in the Spine: Prehistory and ecology of the Jimi-Yuat Valley, Papua New Guinea, pp. 209-223. Townsville: James Cook University of North Queensland.

Fullagar, R. 1992. Lithically Lapita: functional analysis of flaked stone assemblages from West New Britain Province, Papua New Guinea. In J.-C. Galipaud (ed.) Poterie Lapita et Peuplement, pp. 135-143. Noumea: ORSTOM.

Fullagar, R. 1993a. Flaked stone tools and plant food production: a preliminary report on obsidian tools from Talasea, West New Britain, PNG. In P.C. Anderson, S. Beyries, M. Otte and H. Plisson (eds) Traces et Fonction: Les gestes retrouvés, pp. 331-337. vol. 50. Liège: ERAUL.

Fullagar, R. 1993b. Taphonomy and tool use: a role for phytoliths in use-wear and residue analyses. In B.L. Fankhauser and J.R. Bird (eds) Archaeometry: Current Australasian research, pp. 21-27. Occasional Papers in Prehistory, No. 22. Canberra: Department of Prehistory, Research School of Pacific Studies, The Australian National University. 
Fullagar, R. and B. David 1997. Investigating changing attitudes towards an Australian Aboriginal dreaming mountain over $>37,000$ years of occupation via residue and use wear analyses of stone artefacts. Cambridge Archaeological Journal 7(1):139-144.

Fullagar, R. and J. Field 1997. Pleistocene seed-grinding implements from the Australian arid zone. Antiquity 71(272):300-307.

Fullagar, R., J. Field, T.P. Denham and C. Lentfer 2006. Early and mid Holocene tool-use and processing of taro (Colocasia esculenta), yam (Dioscorea sp.) and other plants at Kuk Swamp in the highlands of Papua New Guinea. Journal of Archaeological Science 33:595614.

Fullagar, R. and R. Jones 2004. Usewear and residue analysis of stone artefacts from the Enclosed Chamber, Rocky Cape, Tasmania. Archaeology in Oceania 39(2):79-93.

Fullagar, R., T. Loy and S. Cox 1998. Starch grains, sediments and stone tool function: evidence from Bitokara, Papua New Guinea. In R. Fullagar (ed.) A Closer Look: Recent Australian studies of stone tools, pp. 49-60. Sydney: Archaeological Computing Laboratory, University of Sydney.

Fullagar, R., B. Meehan and R. Jones 1992. Residue analysis of ethnographic plant-working and other tools from Northern Australia. In P. C. Anderson (ed.) Prehistoire de l'Agriculture: Nouvelles Approches Experimentales et Ethnographiques, pp. 39-53. Paris: Editions du Centre National de la Recherche Scientifique.

Furby, J., R. Fullagar, J. Dodson and I. Prosser 1993. The Cuddie Springs bone bed revisited, 1991. In M.A. Smith, M. Spriggs and B.L. Fankhauser (eds) Sahul in Review: Pleistocene archaeology in Australia, New Guinea and Island Melanesia, pp. 204-210. Canberra: Department of Prehistory, Research School of Pacific Studies, The Australian National University.

Furby, J. and T.H. Loy 1994. Analysis of blood residues on stone artefacts from Cuddie Springs, northwestern New South Wales. Paper presented at the Australasian Archaeometry Conference, University of New England, Armidale.

Garling, S.J. 1998. Megafauna on the menu? Haemoglobin crystallisation of blood residues from stone artefacts at Cuddie Springs. In R. Fullagar (ed.) A Closer Look: Recent Australian studies of stone tools, pp. 29-48. Sydney: Archaeological Computing Laboratory, University of Sydney.

Gibson, N.E., L. Wadley and B.S. Williamson 2004. Microscopic residues as evidence of hafting on backed tools from the 60000 to 68000 year-old Howiesons Poort layers of Rose Cottage Cave, South Africa. Southern African Humanities 16:1-11.

Gorman,A. 2000. The Archaeology of Body Modification: The identification of symbolic behaviour through usewear and residues on flaked stone tools. Unpublished $\mathrm{PhD}$ thesis, University of New England.

Grace, R. 1996. Use-wear analysis: the state of the art. Archaeometry 38(2):209-229.

Green, R.C. and D. Anson 2000. Excavations at Kainapirina (SAC), Watom Island, Papua New Guinea. New Zealand Journal of Archaeology 20:29-94.

Hall, J., S. Higgins and R. Fullagar 1989. Plant residues on stone tools. In W. Beck, A. Clarke and L. Head (eds) Plants in Australian Archaeology, pp. 136-160. Tempus. vol. 1. Brisbane: Anthropology Museum, University of Queensland. 
Hanslip, M. 1999. Expedient Technologies? Obsidian artefacts in Island Melanesia. Unpublished $\mathrm{PhD}$ thesis, Australian National University.

Hardy, B L. 1998. Microscopic residue analysis of stone tools from the Middle Paleolithic site of Starosele. In K. Monigal and V. Chabai (eds) The Middle Paleolithic of the Western Crimea, Vol. 2, pp. 179-196. Liege: Etudes et Recherches Archeologiques de l'Universitie de Liege.

Hardy, B L. 2004. Neanderthal behaviour and stone tool function at the Middle Palaeolithic site of La Quina, France. Antiquity 78(301):547-565.

Hardy, B.L. and M. Kay 1998. Stone tool function at Starosele: combining residue and usewear evidence. In K. Monigal and V. Chabai (eds) The Middle Paleolithic of the Western Crimea, Vol. 2, pp. 197-209. Liege: Etudes et Recherches Archeologiques de l'Universitie de Liege.

Hardy, B.L., M. Kay, A.E. Marks and K. Monigal 2001. Stone tool function at the paleolithic sites of Starosele and Buran Kaya III, Crimea: behavioral implications. Proceedings of the National Academy of Sciences 98(19):10972-10977.

Hardy, B.L. and M.J. Rogers 2001. Microscopic investigation of stone tool function from Okote Member sites, Koobi Fora, Kenya [abstract only]. Journal of Human Evolution 40(3):A9.

Haslam, M. 2003. Evidence for maize processing on 2000 year old obsidian artefacts from Copan, Honduras. In D.M. Hart and L.A. Wallis (eds) Phytolith and Starch Research in the Australian-Pacific-Asian Regions: The state of the art, pp. 153-161. Canberra: Pandanus Books.

Haslam, M. 2006a. An archaeology of the instant? Action and narrative in archaeological residue analyses. Journal of Social Archaeology 6(3):402-424.

Haslam, M. 2006b. Archaeological Residue and Starch Analysis: Interpretation and taphonomy. Unpublished PhD thesis. St Lucia: School of Social Science, The University of Queensland.

Haslam, M. 2006c. Potential misidentification of in situ archaeological tool-residues: starch and conidia. Journal of Archaeological Science 33(1):114-121.

Haslam, M. and J. Liston 2008. The use of flaked stone artifacts in Palau, Western Micronesia. Asian Perspectives 47(2):405-428.

Higgins, S. 1988. Starch Grain Differentiation on Archaeological Residues: A feasibility study. Unpublished BA (Hons) thesis. St Lucia: Department of Anthropology and Sociology, The University of Queensland.

Hodder, I. 1991. Reading the Past: Current approaches to interpretation in archaeology. 2nd ed. Cambridge: Cambridge University Press.

Hurcombe, L. M. 1992. Use Wear Analysis and Obsidian: Theory, experiments and results. Sheffield: University of Sheffield.

Hyland, D. C., J. M. Tersak, J. M. Adovasio and M. I. Siegel 1990. Identification of the species of origin of residual blood on lithic material. American Antiquity 55(1):104-112.

Iriarte, J., I. Holst, O. Marozzi, C. Listopad, E. Alonso, A. Rinderknecht and J. Montana 2004. Evidence for cultivar adoption and emerging complexity during the mid-Holocene in the La Plata basin. Nature 432:614-617. 
Jones, R. 1987. Ice-age hunters of the Tasmanian wilderness. Australian Geographic 8:26-45.

Jones, R. 1987. 1990. From Kakadu to Kutikina: the southern continent at 18000 years ago. In C. Gamble and O. Soffer (eds) The World at 18000BP. Low Latitudes, pp. 264-295. London: Unwin Hyman.

Kealhofer, L., R. Torrence and R. Fullagar 1999. Integrating phytoliths within use-wear/residue studies of stone tools. Journal of Archaeological Science 26:527-546.

Keeley, L. and N. Toth 1981. Microwear polishes on early stone tools from Koobi Fora, Kenya. Nature 293:464-465.

Kohn, M. and S. Mithen 1999. Handaxes: products of sexual selection? Antiquity 73:518-526.

Lombard, M. 2004. Distribution patterns of organic residues on Middle Stone Age points from Sibudu Cave, Kwazulu-Natal, South Africa. South African Archaeological Bulletin 59:3744.

Lombard, M. 2005. Evidence of hunting and hafting during the Middle Stone Age at Sibidu Cave, KwaZulu-Natal, South Africa: a multianalytical approach. Journal of Human Evolution 48:279-300.

Lombard, M. 2008. Finding resolution for the Howiesons Poort through the microscope: microresidue analysis of segments from Sibudu Cave, South Africa. Journal of Archaeological Science 35(1):26-41.

Loy, T. H. 1983. Prehistoric blood residues: detection on tool surfaces and identification of species of origin. Science 220:1269-1271.

Loy, T. H. 1985. Preliminary residue analysis: AMNH specimen 20.4/509. In D.H. Thomas (ed.) The Archaeology of Hidden Cave, pp. 224-225. New York: Museum of Natural History Press.

Loy, T. H. 1987. Recent advances in blood residue analysis. In W.R. Ambrose and J.M.J. Mummery (eds) Archaeometry: Further Australasian Studies, pp. 57-65. Canberra: Australian National University.

Loy, T. H. 1990. Getting blood from a stone. Australian Natural History 23(6):470-479.

Loy, T. H. 1991. Prehistoric organic residues: recent advances in identification, dating and their antiquity. In W. Wagner and A. Pernicka (eds) Archaeometry '90: Proceedings of the 27th International Symposium on Archaeometry, pp. 645-656. Boston: Birkhauser Verlag.

Loy, T. H. 1993. The artefact as site: an example of the biomolecular analysis of organic residues on prehistoric tools. World Archaeology 25(1):44-63.

Loy, T. H. 1994. Residue analysis of artifacts and burned rock from the Mustang Branch and Barton sites (41HY209 and 41HY202). In R.A. Ricklis and M B. Collins (eds) Archaic and Late Prehistoric Human Ecology in the Middle Onion Creek Valley, Hays County, Texas, pp. 607-627. vol. 2. Austin, Texas: Texas Archaeological Research Laboratory, The University of Texas at Austin.

Loy, T. H. 1998. Blood on the axe. New Scientist 159(2151):40-43.

Loy, T.H. and E.J. Dixon 1998. Blood residues on fluted points from eastern Beringia. American Antiquity 63(1):21-46. 
Loy, T H. and B.L. Hardy 1992. Blood residue analysis of 90,000-year-old stone tools from Tabun Cave, Israel. Antiquity 66:24-35.

Loy, T.H., K. Kuman, J. Halliday and P. Unwins 1999. Organic residues on 2Myr Oldowan tools from Sterkfontein Cave, South Africa. In Abstracts of the 64th Annual Meeting of the Society for American Archaeology. Chicago: Society for American Archaeology.

Loy, T. H. and D. E. Nelson 1986. Potential applications of the organic residues on ancient tools. In J.S. Olin and M.J. Blackman (eds) Proceedings of the 24th International Archaeometry Symposium, pp. 179-185. Smithsonian Institution Press, Washington, D.C.

Loy, T. H., M. Spriggs and S. Wickler 1992. Direct evidence for human use of plants 28,000 years ago: starch residues on stone artefacts from the northern Solomon Islands. Antiquity 66:898-912.

Loy, T. H. and A. R. Wood 1989. Blood residue analysis at Cayönü Tepesi, Turkey. Journal of Field Archaeology 16:451-60.

Lu, T. 2003. Starch residue analysis of the Zengpiyan tools. In F. Xiangou (ed.) Zengpiyan-A Prehistoric Cave in South China, pp. 646-651. Beijing: Cultural Relics Publishing House.

Mazza, P.P.A., F. Martini, B. Sala, M. Magi, M.P. Colombini, G. Giachi, F. Landucci, C. Lemorini, F. Modungo and E. Ribechini 2006. A new Palaeolithic discovery: tar-hafted stone tools in a European Mid-Pleistocene bone-bearing bed. Journal of Archaeological Science 33(9):1310-1318.

McBryde, I. 1974. Aboriginal Prehistory in New England. Sydney: Sydney University Press.

McBryde, I. 1984. Backed blade industries from the Grama rock shelters, New South Wales: some evidence on function. In V.N. Misra and P. Bellwood (eds) Recent Advances in IndoPacific Prehistory, pp. 231-249. New Delhi: Oxford \& IBH Publishing Co..

Morwood, M. 1981. Archaeology of the central Queensland highlands: the stone component. Archaeology in Oceania 16(1):1-52.

Mueller, J.W. (ed.) 1975. Sampling in Archaeology. Tuscon: University of Arizona Press.

Nelson, D E., T.H. Loy, J. Vogel and J. Southon 1986. Radiocarbon dating blood residues on prehistoric stone tools. Radiocarbon 28(1):170-174.

Newman, M. and P. Julig 1989. The identification of protein residues on artifacts from a stratified boreal forest site. Canadian Journal of Archaeology 13:119-132.

Orton, C. 2000. Sampling in Archaeology. Cambridge: Cambridge University Press.

Pagan Jimenez, J.R., M.A. Rodriguez Lopez, L.A. Chanlatte Baik and Y. Narganes Storde 2005. La temprana introducción y uso de algunas plantas domésticas, silvestres y cultivos en Las Antillas precolombinas: una primera revaloración desde la perspectiva del "arcaico" de Vieques y Puerto Rico. Diálogo Antropológico 3(10):7-33.

Paull, W. 1984. Organic residue analysis of stone and bone tools. In M.P.R. Magne and R.G. Matson (eds) Athapaskan and Earlier Archaeology at Big Eagle Lake, British Columbia, pp. 239-266. Unpublished report to the Social Sciences and Humanities Research Council of Canada.

Pavlides, C. 2004. From Misisil Cave to Eliva Hamlet: rediscovering the Pleistocene in interior West New Britain. In V. Attenbrow and R. Fullagar (ed.) A Pacific Odyssey: Archaeology 
and Anthropology in the Western Pacific. Papers in Honour of Jim Specht, pp. 97-108. Sydney: Australian Museum.

Pawlik, A.F. 2004a. An Early Bronze Age pocket lighter. In E.A. Walker, F. Wenban-Smith and F. Healy (eds) Lithics in Action, pp. 149-151. Oxford: Lithic Studies Society Occasional Paper No. 8. Oxbow Books.

Pawlik, A.F. 2004b. Identification of hafting traces and residues by scanning electron microscopy and energy-dispersive analysis of X-rays. In E.A. Walker, F. Wenban-Smith and F. Healy (eds) Lithics in Action, pp. 169-179. Oxford: Lithic Studies Society Occasional Paper No. 8. Oxbow Books.

Pearsall, D. 2003. Integrating biological data: phytoliths and starch grains, health and diet, at Real Alto, Ecuador. In D.M. Hart and L.A. Wallis (eds) Phytolith and Starch Research in the Australian-Pacific-Asian Regions: The state of the art. pp. 187-200. Canberra: Pandanus Books.

Pearsall, D., K. Chandler-Ezell and J.A. Zeidler 2004. Maize in ancient Ecuador: results of residue analysis of stone tools from the Real Alto site. Journal of Archaeological Science 31:423442.

Perry, L. 2002. Starch analyses reveal multiple functions of quartz "manioc" grater flakes from the Orinoco Basin, Venezuela. Interciencia 27(11):635-639.

Perry, L. 2004. Starch analyses reveal the relationship between tool type and function: an example from the Orinoco valley of Venezuela. Journal of Archaeological Science 31:1069-1081.

Perry, L. 2005. Reassessing the traditional interpretation of "manioc" artifacts in the Orinoco Valley of Venezuela. Latin American Antiquity 16(4):409-426.

Perry, L., D.H. Sandweiss, D.R. Piperno, K. Rademaker, M.A. Malpass, A. Umire and P. de la Vera 2006. Early maize agriculture and interzonal interaction in southern Peru. Nature 440:76-79.

Petraglia, M., S.L. Bupp, S.P. Fitzell and K.W. Cunningham (eds) 2002. Hickory Bluff: Changing perceptions of Delmarva archaeology. Delaware Department of Transportation Archaeology Series No. 175.

Piperno, D.R. and I. Holst 1998. The presence of starch grains on prehistoric stone tools from the humid neotropics: indications of early tuber use and agriculture in Panama. Journal of Archaeological Science 25:765-776.

Piperno, D.R., A.J. Ranere, I. Holst and P. Hansell 2000. Starch grains reveal early root crop horticulture in Panamanian tropical forest. Nature 407:894-897.

Piperno, D R., E. Weiss, I. Holst and D. Nadel 2004. Procesing of wild cereal grains in the Upper Palaeolithic revealed by starch grain analysis. Nature 430:670-673.

Potter, D. 1994. Strat 55, Operation 2012, and comments on lowland Maya blood ritual. In T.R. Hester, H.J. Shafer and J.D. Eaton (eds) Continuing Archeology at Colha, Belize, pp. 3137. Texas Archaeological Research Laboratory, The University of Texas at Austin, Austin.

Redman, C.L. 1974. Archaeological Sampling Strategies. Reading, Mass: Addison-Wesley.

Richards, T. 1989. Initial results of a blood residue analysis of lithic artefacts from Thorpe Common rockshelter, South Yorkshire. In I.P. Brooks and P. Phillips (eds) Breaking the Stony Silence: Papers from the Sheffield Lithics Conference 1988, pp. 73-90. Oxford: British Archaeological Reports British Series 213. 
Ringrose, T J. 1993. Bone counts and statistics: a critique. Journal of Archaeological Science 29:121-157.

Risberg, J., L. Bengtsson, B. Kihlstedt, C. Lidstrom Holmberg, M. Olausson, E. Olsson and C. Tingvall 2002. Siliceous microfossils, especially phytoliths, as recorded in five prehistoric sites in Eastern Middle Sweden. Journal of Nordic Archaeological Science 13:11-26.

Robertson, G. 1996. An application of environmental scanning electron microscopy and image analysis to starch grain differentiation. Tempus 6:169-182.

Robertson, G. 2002. Birds of a feather stick: microscopic feather residues on stone artefacts from Deep Creek Shelter, New South Wales. Tempus 7:175-182.

Robertson, G. 2005. Backed Artefact Use in Eastern Australia: A residue and use-wear analysis. Unpublished PhD thesis, University of Queensland.

Rots, V. and B.S. Williamson 2004. Microwear and residue analyses in perspective: the contribution of ethnoarchaeological evidence. Journal of Archaeological Science 31:1287-1299.

Shafer, H. and R. Holloway 1979. Organic residue analysis in determining stone tool function. In B. Hayden (ed.) Lithic Use-Wear Analysis, pp. 385-399. New York: Academic Press.

Shanks, O.C., M. Kornfeld and D.D. Hawk 1999. Protein analysis of Bugas-Holding tools: new trends in immunological studies. Journal of Archaeological Science 26:1183-1191.

Sievert, A.K. 1990. Postclassic Maya ritual behaviour: microwear analysis of stone tools from ceremonial contexts. In B. Graslund, H. Knutsson, K. Knuttson and J. Taffinder (eds) The Interpretative Possibilities of Microwear Studies, pp. 147-157. Uppsala: Societas Archaologica Upsaliensis.

Sievert, A.K. 1992a. Maya Ceremonial Specialisation: Lithic tools from the sacred cenote at Chichen Itza, Yucatan. Madison: Prehistory Press.

Sievert, A.K. 1992b. Use-wear analysis of chipped stone tools. In C.C. Coggins (ed.) Artifacts from the Cenote of Sacrifice, Chichen Itza, Yucatan, pp. 182-187. Cambridge, Mass: Peabody Museum of Archaeology and Ethnology, Harvard University.

Slack, M., R. Fullagar, J. Field and A. Border 2004. New Pleistocene ages for backed artefact technology in Australia. Archaeology in Oceania 39(3):131-137.

Smith, M.A. 2004. The grindstone assemblage from Puritjarra rock shelter: investigating the history of seed-based economies in arid Australia. In T. Murray (ed.) Archaeology From Australia, pp. 168-186. Melbourne: Australian Scholarly Publishing.

Sobolik, K.D. 1996. Lithic organic residue analysis: an example from the Southwestern Archaic. Journal of Field Archaeology 23(4):461-469.

Turner, M., A. Anderson and R. Fullagar 2001. Stone artefacts from the Emily Bay Settlement Site, Norfolk Island. In A. Anderson and P. White (eds) The Prehistoric Archaeology of Norfolk Island, Southwest Pacific, pp. 53-66. Records of the Australian Museum, Supplement 27. Sydney: Australian Museum.

Tuross, N. and T.D. Dillehay 1995. The mechanism of organic preservation at Monte Verde, Chile, and one use of biomiolecules in archaeological interpretation. Journal of Field Archaeology 22(1):97-110.

Van Peer, P., R. Fullagar, S. Stokes, R.M. Bailey, J. Moeyersons, F. Steenhoudt, A. Geerts, T. Vanderbeken, M. De Dapper and F. Geus 2003. The Early to Middle Stone Age transition 
and the emergence of modern human behaviour at site 8-B-11, Sai Island, Sudan. Journal of Human Evolution 45:187-193.

Veth, P., R. Fullagar and R. Gould 1997. Residue and use-wear analysis of grinding implements from Puntutjarpa Rockshelter in the Western Desert: current and proposed research. Australian Archaeology 44:23-25.

Villa, P., A. Delagnes and L. Wadley 2005. A late Middle Stone Age artifact assemblage from Sibudu (KwaZulu-Natal): comparisons with the European Middle Paleolithic. Journal of Archaeological Science 32:399-422.

Wadley, L., B.S. Williamson and M. Lombard 2004. Ochre in hafting in Middle Stone Age southern Africa: a practical role. Antiquity 78(301):661-675.

Wallis, L. and S. O'Connor 1998. Residues on a sample of stone points from the west Kimberley. In R. Fullagar (ed.) A Closer Look: Recent Australian studies of stone tools, pp. 149-178. Sydney: Archaeological Computing Laboratory, University of Sydney.

Weisler, M.I. and M. Haslam 2005. Determining the function of Polynesian volcanic glass artifacts: results of a residue study. Hawaiian Archaeology 10:1-17.

Whittaker, J.C. and G. McCall 2001. Hand-axe-hurling hominids: an unlikely story. Current Anthropology 42(4): 566-572.

Williamson, B.S. 1996. Preliminary stone tool residue analysis from Rose Cottage Cave. South African Field Archaeology 5:36-44.

Williamson, B.S. 1997. Down the microscope and beyond: microscopy and molecular studies of stone tool residues and bone samples from Rose Cottage Cave. South African Journal of Science 93:458-464.

Williamson, B.S. 2004. Middle stone age tool function from residue analysis at Sibudu Cave. South African Journal of Science 100(3-4):174-178.

Wood, A.R. 1998. Revisited: blood residue investigations at Cayönü, Turkey. In G. Arsebuk, M.J. Mellink and W. Schirmer (eds) Light on Top of the Black Hill: Studies presented to Halet Cambel, pp. 763-764. Istanbul: Ege Yayinlari.

Zarillo, S. and B. Kooyman 2006. Evidence for berry and maize processing on the Canadian plains from starch grain analysis. American Antiquity 71(3):473-500. 


\section{APPENDIX: ARCHAEOLOGICAL MICROSCOPIC ANALYSES OF RESIDUES ON STONE ARTEFACTS.}

\begin{tabular}{|c|c|c|c|c|c|c|c|}
\hline Year & Author(s) & $\begin{array}{l}\text { Site, age } \\
\text { (approx.) }\end{array}$ & $\#^{1}$ & Mag. ${ }^{2}$ & $U-w^{3}$ & Journal $^{4}$ & Summary \\
\hline 2006 & $\begin{array}{l}\text { Mazza, } \\
\text { Martini et al. }\end{array}$ & $\begin{array}{l}\text { Campitello } \\
\text { Quarry, Upper } \\
\text { Valdarno Basin, } \\
\text { Italy, Middle } \\
\text { Pleistocene }\end{array}$ & 3 & $0.74-70 x$ & $\mathrm{Y}$ & JAS & $\begin{array}{l}\text { Flakes examined via low- } \\
\text { power analysis. Revealed } \\
\text { traces of hafting resin on } \\
\text { one artefact and abundant } \\
\text { resin on another. Subsequent } \\
\text { chemical analyses suggest } \\
\text { Betulaceae trees as the origin } \\
\text { of the resin/tar. }\end{array}$ \\
\hline 2006 & $\begin{array}{l}\text { Fullagar, } \\
\text { Field et al. }\end{array}$ & $\begin{array}{l}\text { Kuk Swamp, } \\
\text { Papua New } \\
\text { Guinea, } \\
<10,220 \text { BP }\end{array}$ & 55 & $6-1000 x$ & $\mathrm{Y}$ & JAS & $\begin{array}{l}\text { Examined } 55 \text { artefacts to } \\
\text { assess residue presence and } \\
\text { preservation, then examined } \\
12 \text { artefacts for taro and yam } \\
\text { starch specifically - } 11 \text { of } \\
\text { these had starches. }\end{array}$ \\
\hline 2006 & Haslam & $\begin{array}{l}\text { Palau, } \\
\text { Micronesia; } \\
\text { Copan, } \\
\text { Honduras }\end{array}$ & - & $\begin{array}{l}100- \\
1000 x\end{array}$ & - & JAS & $\begin{array}{l}\text { Few details on number or } \\
\text { age of analysed artefacts. } \\
\text { Identified fungal elements } \\
\text { (conidia, hyphae) and noted } \\
\text { the potential for confusion } \\
\text { with starch granules. }\end{array}$ \\
\hline 2006 & $\begin{array}{l}\text { Perry, } \\
\text { Sandweiss } \\
\text { et al. }\end{array}$ & $\begin{array}{l}\text { Waynuna, Peru, } \\
3600-4000 B P\end{array}$ & 3 & $200 x$ & - & Nature & $\begin{array}{l}\text { Starch removed from } \\
\text { unwashed grindstones } \\
\text { and separated with } \mathrm{CsCl} \text {. } \\
\text { Discusses plant use and } \\
\text { migration from various } \\
\text { microfossils. Identified maize, } \\
\text { arrowroot and possible potato } \\
\text { starches. }\end{array}$ \\
\hline 2006 & $\begin{array}{l}\text { Zarillo \& } \\
\text { Kooyman }\end{array}$ & $\begin{array}{l}\text { Alberta, } \\
\text { Canada, pre- } \\
\text { European } \\
\text { contact }\end{array}$ & 3 & $400-630 x$ & $Y$ & Am Ant & $\begin{array}{l}\text { Analysed two washed } \\
\text { grinding tools and one flake } \\
\text { tool. Starch from choke } \\
\text { cherry, saskatoon and maize } \\
\text { was identified, with tentative } \\
\text { starch identification of prairie } \\
\text { turnip and Graminae }\end{array}$ \\
\hline 2005 & Lombard & $\begin{array}{l}\text { Sibudu Cave, } \\
\text { South Africa, } \\
51-62 \text { ka }\end{array}$ & 50 & $50-500 x$ & $Y$ & JHE & $\begin{array}{l}\text { Identified various plant, } \\
\text { animal and mineral residues, } \\
\text { including hafting resins. } \\
\text { Posited hunting tool-use. }\end{array}$ \\
\hline 2005 & Perry & $\begin{array}{l}\text { Pozo Azul } \\
\text { Norte-1, } \\
\text { Venezuela, } \\
\text { 1200-1500BP }\end{array}$ & 7 & $10-400 x$ & $Y$ & LAA & $\begin{array}{l}\text { Identified starches on } \\
\text { quartz microliths; testing } \\
\text { interpretations of microlith } \\
\text { use based on ethnohistoric } \\
\text { records. }\end{array}$ \\
\hline 2005 & $\begin{array}{l}\text { Weisler \& } \\
\text { Haslam }\end{array}$ & $\begin{array}{l}\text { Molokai, } \\
\text { Hawaii, 300- } \\
\text { 400BP } \\
\text { Henderson Is. } \\
\text { Pitcairn Group, } \\
\text { 400-1000BP }\end{array}$ & $\begin{array}{l}14 \\
15\end{array}$ & $\begin{array}{l}100- \\
1000 x\end{array}$ & $\mathrm{Y}$ & $\mathrm{HA}$ & $\begin{array}{l}\text { Studied small volcanic glass } \\
\text { flakes from two Pacific islands } \\
\text { in an initial cataloguing } \\
\text { of past uses. Found plant } \\
\text { tissue, feather, starch. Uses } \\
\text { identified are not assumed to } \\
\text { be universal. }\end{array}$ \\
\hline 2004 & $\begin{array}{l}\text { Fullagar \& } \\
\text { Jones }\end{array}$ & $\begin{array}{l}\text { Rocky Cape, } \\
\text { Tasmania, } \\
\text { Australia, 6.7ka }\end{array}$ & 150 & $50-500 x$ & $Y$ & $\mathrm{AO}$ & $\begin{array}{l}\text { Identified } 43 \text { used artefacts } \\
\text { with residues present } \\
\text { including general plant tissue, } \\
\text { wood, starch, skin, and bone. } \\
\text { Some discussion of activity } \\
\text { areas. }\end{array}$ \\
\hline 2004 & $\begin{array}{l}\text { Gibson, } \\
\text { Wadley et al. }\end{array}$ & $\begin{array}{l}\text { Rose Cottage } \\
\text { Cave, South } \\
\text { Africa, 60-68ka }\end{array}$ & 48 & $50-800 x$ & $\mathrm{Y}$ & $\mathrm{SAH}$ & $\begin{array}{l}\text { Identified plant tissues, } \\
\text { blood, ochre and modern } \\
\text { contaminants. Starch grains } \\
\text { were present on all artefacts. } \\
\text { Discussion of hafting. }\end{array}$ \\
\hline
\end{tabular}




\begin{tabular}{|c|c|c|c|c|c|c|c|}
\hline Year & Author(s) & $\begin{array}{l}\text { Site, age } \\
\text { (approx.) }\end{array}$ & $\#^{1}$ & Mag. $^{2}$ & $U-w^{3}$ & Journal ${ }^{4}$ & Summary \\
\hline 2004 & Hardy & $\begin{array}{l}\text { La Quina, } \\
\text { France, ca. 40- } \\
70 \mathrm{ka}\end{array}$ & 300 & $50-500 x$ & $\bar{Y}$ & Antiquity & $\begin{array}{l}106 \text { artefacts had residues, } \\
\text { which included plant tissue, } \\
\text { pollen, raphides, hair, bone } \\
\text { feather and possible blood. } \\
\text { Plant residues observed on } \\
10 \text { of } 16 \text { previously washed } \\
\text { tools. Discussion of plant vs } \\
\text { animal exploitation. }\end{array}$ \\
\hline 2004 & $\begin{array}{l}\text { Iriarte, Holst } \\
\text { et al. }\end{array}$ & $\begin{array}{l}\text { Los Ajos, } \\
\text { Uruguay, } \\
\text { 3500BP }\end{array}$ & 3 & $100-400 x$ & - & Nature & $\begin{array}{l}\text { Maize starch granules (total } \\
n=17 \text { ) recovered from } 3 \\
\text { milling stones. Methods } \\
\text { reference Piperno et al. } \\
(2000) \text {. }\end{array}$ \\
\hline 2004 & Lombard & $\begin{array}{l}\text { Sibudu Cave, } \\
\text { South Africa, } \\
51-61 \mathrm{ka}\end{array}$ & 24 & $50-500 x$ & $Y$ & SAAB & $\begin{array}{l}\text { Uses floral and faunal residue } \\
\text { distributions to infer hafting } \\
\text { and subsistence activities (i.e. } \\
\text { hunting) }\end{array}$ \\
\hline 2004 & Pavlides & $\begin{array}{l}\text { Yombon, West } \\
\text { New Britain, } \\
\text { late Pleistocene }\end{array}$ & 3 & - & $Y$ & - & $\begin{array}{l}\text { In A Pacific Odyssey. Few } \\
\text { details provided, but plant } \\
\text { processing (wood/starch) } \\
\text { identified. }\end{array}$ \\
\hline 2004 & Pawlik & $\begin{array}{l}\text { Bornheim- } \\
\text { Sechtem, } \\
\text { Rhine Valley, } \\
\text { Germany, } \\
\text { 3500BP }\end{array}$ & 1 & - & $Y$ & - & $\begin{array}{l}\text { In Lithics in Action. Flint } \\
\text { artefact from a grave site } \\
\text { identified as a 'prehistoric } \\
\text { pocket lighter' through light } \\
\text { microscopy and subsequent } \\
\text { SEM-EDAX of the tool and } \\
\text { an associated haematite } \\
\text { fragment. }\end{array}$ \\
\hline 2004 & Pawlik & $\begin{array}{l}\text { Ullafelsen, } \\
\text { Tyrolian Alps, } \\
\text { Austria, 10.5- } \\
11 \text { ka } \\
\text { Henauhof-Nord } \\
\text { II, Germany, } \\
\text { Mesolithic }\end{array}$ & 110 & - & $Y$ & - & $\begin{array}{l}\text { In Lithics in Action. } 25 \\
\text { siliceous artefacts from } \\
\text { Ullafelsen had tar-like } \\
\text { hafting residues identified } \\
\text { by light microscopy. SEM } \\
\text { subsequently used to } \\
\text { characterise the tar. No } \\
\text { magnification data. No data } \\
\text { on number of artefacts from } \\
\text { Henauhof-Nord - these } \\
\text { artefacts also had hafting } \\
\text { residues with embedded plant } \\
\text { fragments visible using SEM. }\end{array}$ \\
\hline 2004 & $\begin{array}{l}\text { Pearsall, } \\
\text { Chandler- } \\
\text { Ezell et al. }\end{array}$ & $\begin{array}{l}\text { Real Alto, } \\
\text { Ecuador, 2400- } \\
\text { 2800BP }\end{array}$ & 17 & $312-500 x$ & - & JAS & $\begin{array}{l}\text { Samples collected by } \\
\text { brushing, washing and } \\
\text { sonication from ground stone } \\
\text { and cobbles. Maize starch } \\
\text { recovered from all tools; } \\
\text { most effective method was } \\
\text { sonication. Some starch } \\
\text { separated with CsCl. See also } \\
\text { Pearsall (2003) and Chandler- } \\
\text { Ezell et al. (2006). }\end{array}$ \\
\hline 2004 & Perry & $\begin{array}{l}\text { Orinoco valley, } \\
\text { Venezuela, } \\
500-1000 \mathrm{BP}\end{array}$ & 10 & $10-400 x$ & $\mathrm{~N}$ & JAS & $\begin{array}{l}\text { Studied ground stone and } \\
\text { flake tools, by microscopy } \\
\text { and removal of residue by } \\
\text { spot sampling and sonication. } \\
\text { Identified arrowroot, maize, } \\
\text { ginger and grass (Poaceae) } \\
\text { starch. Results compared with } \\
\text { macrobotanical remains. }\end{array}$ \\
\hline 2004 & $\begin{array}{l}\text { Piperno, } \\
\text { Weiss et al. }\end{array}$ & $\begin{array}{l}\text { Ohalo II, Israel, } \\
22.5-23.5 \mathrm{ka}\end{array}$ & 1 & $400 x$ & $\mathrm{~N}$ & Nature & $\begin{array}{l}\text { Starch grains identified in } \\
\text { residue removed from a } \\
\text { grindstone. Identified grass- } \\
\text { seed starches, including } \\
\text { Hordeum sp. Earliest direct } \\
\text { evidence for human grass- } \\
\text { seed processing. }\end{array}$ \\
\hline
\end{tabular}




\begin{tabular}{|c|c|c|c|c|c|c|c|}
\hline Year & Author(s) & $\begin{array}{l}\text { Site, age } \\
\text { (approx.) }\end{array}$ & $\#^{1}$ & Mag. $^{2}$ & $U-w^{3}$ & Journal $^{4}$ & Summary \\
\hline 2004 & $\begin{array}{l}\text { Rots \& } \\
\text { Williamson }\end{array}$ & $\begin{array}{l}\text { Southern } \\
\text { Ethiopia, } \\
\text { modern }\end{array}$ & 18 & $50-800 x$ & $\mathrm{Y}$ & JAS & $\begin{array}{l}\text { Compared ethnographic with } \\
\text { archaeological scrapers. } \\
\text { Found very few residues } \\
\text { on the archaeological tools, } \\
\text { including starch, blood and } \\
\text { ochre. }\end{array}$ \\
\hline 2004 & $\begin{array}{l}\text { Slack, } \\
\text { Fullagar et al. }\end{array}$ & $\begin{array}{l}\text { Old Lilydale } \\
\text { Homestead } \\
\text { (OLH), QLD, } \\
\text { Australia, 15ka; } \\
\\
\text { GRE8, QLD, } \\
\text { Australia, 15ka }\end{array}$ & 1 & $200 x$ & $\mathrm{Y}$ & $\mathrm{AO}$ & $\begin{array}{l}\text { Backed artefacts; few specific } \\
\text { details of the residue study } \\
\text { are provided, however. Found } \\
\text { starch and 'dark smears' on } \\
\text { the OLH tool, and greasy } \\
\text { films and starch granules on } \\
\text { one of the GRE8 tools. }\end{array}$ \\
\hline 2004 & Smith & $\begin{array}{l}\text { Puritjarra rock } \\
\text { shelter, NT, } \\
\text { Australia }\end{array}$ & 56 & $10-625 x$ & $\mathrm{Y}$ & - & $\begin{array}{l}\text { In Archaeology From } \\
\text { Australia. Examined } \\
\text { grindstones for starch. } \\
\text { Also tested for blood (with } \\
\text { Hemastix) and plant alkaloids. } \\
\text { Observed starch most closely } \\
\text { matched acacia; starch was } \\
\text { also observed in abundance } \\
\text { on non-cultural gravels and in } \\
\text { site sediments. }\end{array}$ \\
\hline 2004 & $\begin{array}{l}\text { Wadley, } \\
\text { Williamson } \\
\text { et al. }\end{array}$ & $\begin{array}{l}\text { Sibudu Cave, } \\
\text { South Africa, } \\
26-60 k a\end{array}$ & 531 & $50-800 x$ & $\mathrm{Y}$ & Antiquity & $\begin{array}{l}\text { Focused on ochre residues, } \\
\text { also observed plant residues } \\
\text { (e.g. tissue, fibres, starch, } \\
\text { exudate). }\end{array}$ \\
\hline 2004 & Williamson & $\begin{array}{l}\text { Sibudu Cave, } \\
\text { South Africa, } \\
\text { Middle Stone } \\
\text { Age }\end{array}$ & 412 & $50-800 x$ & $\mathrm{Y}$ & SAJS & $\begin{array}{l}\text { Residues found include } \\
\text { starch, collagen, blood, } \\
\text { ochre, fungi, hair, plant tissue. } \\
\text { Results discussed in terms of } \\
\text { plant vs animal processing. }\end{array}$ \\
\hline 2003 & $\begin{array}{l}\text { Babot \& } \\
\text { Apella }\end{array}$ & $\begin{array}{l}\text { Tucuman, } \\
\text { Argentina, 1.5- } \\
\text { 2ka }\end{array}$ & 1 & $400 x$ & $\mathrm{~N}$ & $\begin{array}{l}\text { Archaeo- } \\
\text { metry }\end{array}$ & $\begin{array}{l}\text { Maize starch identified on a } \\
\text { grindstone, in conjunction with } \\
\text { ground bone residue. }\end{array}$ \\
\hline 2003 & $\begin{array}{l}\text { Denham, } \\
\text { Haberle et al. }\end{array}$ & $\begin{array}{l}\text { Kuk Swamp, } \\
\text { Papua New } \\
\text { Guinea, 6.5- } \\
\text { 10ka }\end{array}$ & 3 & - & $\mathrm{Y}$ & Science & $\begin{array}{l}\text { Identified Colocasia esculenta } \\
\text { (taro) starch. Very limited } \\
\text { report - does not include } \\
\text { microscope or magnification } \\
\text { information, or provide } \\
\text { photographs. }\end{array}$ \\
\hline 2003 & Haslam & $\begin{array}{l}\text { Copan, } \\
\text { Honduras, } \\
\text { 1900-2050BP }\end{array}$ & 150 & $\begin{array}{l}100- \\
1000 x\end{array}$ & $Y$ & - & $\begin{array}{l}\text { In Phytolith and Starch } \\
\text { Research. Maize residues } \\
\text { identified on obsidian and } \\
\text { other artefacts via starch } \\
\text { grains and plant tissue. }\end{array}$ \\
\hline 2003 & Lu & $\begin{array}{l}\text { Zengpiyan, } \\
\text { China, 7-12ka }\end{array}$ & 80 & - & $\mathrm{Y}$ & - & $\begin{array}{l}\text { In Zengpiyan-A Prehistoric } \\
\text { Cave in South China. } 80 \\
\text { pebble tools examined for } \\
\text { starch. Grass family and taro } \\
\text { starch found on } 11 \text { tools. }\end{array}$ \\
\hline 2003 & $\begin{array}{l}\text { Van Peer, } \\
\text { Fullagar, } \\
\text { et al. }\end{array}$ & $\begin{array}{l}\text { Sai Island, } \\
\text { Sudan, 180- } \\
\text { 220ka }\end{array}$ & 2 & - & $\mathrm{Y}$ & JHE & $\begin{array}{l}\text { Very little information } \\
\text { provided. Phytolith and starch } \\
\text { granules in residues removed } \\
\text { from quartzite cobbles. }\end{array}$ \\
\hline 2002 & $\begin{array}{l}\text { Akerman, } \\
\text { Fullagar et al. }\end{array}$ & $\begin{array}{l}\text { Keep River } \\
\text { region, NT, } \\
\text { Australia, late } \\
\text { Holocene }\end{array}$ & 15 & $\begin{array}{l}100- \\
1000 x\end{array}$ & $\mathrm{Y}$ & AAS & $\begin{array}{l}\text { No specific dates reported. } \\
\text { Identified resin, ochre and } \\
\text { plant tissue. Archaeological } \\
\text { results are discussed in } \\
\text { conjunction with residue study } \\
\text { of ethnographic material. }\end{array}$ \\
\hline 2002 & $\begin{array}{l}\text { Risberg, } \\
\text { Bengtsson } \\
\text { et al. }\end{array}$ & $\begin{array}{l}\text { Various sites, } \\
\text { Sweden, 4.6- } \\
\text { 5.7ka }\end{array}$ & 6 & $1000 x$ & $\mathrm{Y}$ & JNAS & $\begin{array}{l}\text { Grindstone residues from } \\
\text { three sites examined for } \\
\text { siliceous particles (e.g. } \\
\text { diatoms, phytoliths) and } \\
\text { starch. }\end{array}$ \\
\hline 2002 & Robertson & $\begin{array}{l}\text { Deep Creek } \\
\text { Shelter, NSW, } \\
\text { Australia, } \\
\text { 1-3.5ka }\end{array}$ & 41 & $6-1000 x$ & $\mathrm{Y}$ & Tempus & $\begin{array}{l}\text { Only feather residues } \\
\text { reported for these artefacts, } \\
\text { although other residues } \\
\text { were present (see Robertson } \\
\text { 2005). }\end{array}$ \\
\hline
\end{tabular}




\begin{tabular}{|c|c|c|c|c|c|c|c|}
\hline Year & Author(s) & $\begin{array}{l}\text { Site, age } \\
\text { (approx.) }\end{array}$ & $\#^{1}$ & Mag. $^{2}$ & $U-w^{3}$ & Journal $^{4}$ & Summary \\
\hline 2001 & $\begin{array}{l}\text { Balme, } \\
\text { Garbin et al. }\end{array}$ & $\begin{array}{l}\text { Puntutjarpa } \\
\text { Rockshelter, } \\
\text { WA, Australia, } \\
\text { modern-10ka }\end{array}$ & 49 & $50-800 x$ & $Y$ & AA & $\begin{array}{l}\text { Grindstone study. Most tools } \\
\text { had starch residue, some had } \\
\text { blood, ochre, hair, plant fibres. } \\
\text { Results discussed in terms of } \\
\text { seed grinding. }\end{array}$ \\
\hline 2001 & $\begin{array}{l}\text { Dominguez- } \\
\text { Rodrigo, } \\
\text { Serralonga, } \\
\text { et al. }\end{array}$ & $\begin{array}{l}\text { Peninj, } \\
\text { Tanzania, ca. } \\
1.5 \mathrm{Ma}\end{array}$ & 5 & $400 x+$ & $\mathrm{N}$ & JHE & $\begin{array}{l}\text { Identified siliceous phytoliths, } \\
\text { calcium oxalate crystals } \\
\text { and plant tissues on the } \\
\text { artefacts and surrounding } \\
\text { soils. Suggest a woodworking } \\
\text { function for handaxes. }\end{array}$ \\
\hline 2001 & $\begin{array}{l}\text { Hardy, Kay } \\
\text { et al. }\end{array}$ & $\begin{array}{l}\text { Buran Kaya } \\
\text { III, Crimea, } \\
\text { Ukraine, 32- } \\
37 \text { ka }\end{array}$ & 19 & $100-500 x$ & $\mathrm{Y}$ & PNAS & $\begin{array}{l}\text { Evidence of hafting and } \\
\text { use on plants and animals. } \\
\text { Residues include hair, } \\
\text { feathers, plant tissue, starch } \\
\text { grains, raphides. Some } \\
\text { discussion of plant vs animal } \\
\text { use. This study also re- } \\
\text { presents some of the residue } \\
\text { results from Hardy (1998). }\end{array}$ \\
\hline 2001 & $\begin{array}{l}\text { Turner, } \\
\text { Anderson } \\
\text { et al. }\end{array}$ & $\begin{array}{l}\text { Emily Bay, } \\
\text { Norfolk Island }\end{array}$ & 15 & $10-1000 x$ & $\mathrm{Y}$ & RAM & $\begin{array}{l}\text { No dates provided. Analysed } \\
10 \text { basalt, } 5 \text { obsidian } \\
\text { artefacts. } 4 \text { artefacts had } \\
\text { starch }(<1 \mu \mathrm{m}) \text {. Some plant } \\
\text { tissue residues. }\end{array}$ \\
\hline 2000 & $\begin{array}{l}\text { Green \& } \\
\text { Anson }\end{array}$ & $\begin{array}{l}\text { Kainapirina } \\
\text { (SAC), Watom } \\
\text { Island, Papua } \\
\text { New Guinea, } \\
\text { 1850-2400BP }\end{array}$ & - & - & $Y$ & NZJA & $\begin{array}{l}\text { Very little information } \\
\text { provided. Highly weathered } \\
\text { obsidian was studied, } \\
\text { resulting in little residue (or } \\
\text { use-wear) information. See } \\
\text { Hanslip (1999). }\end{array}$ \\
\hline 2000 & $\begin{array}{l}\text { Piperno, } \\
\text { Ranere et al. }\end{array}$ & $\begin{array}{l}\text { Aguadulce } \\
\text { shelter, } \\
\text { Panama, 5-7ka }\end{array}$ & 19 & $100-400 x$ & $\mathrm{~N}$ & Nature & $\begin{array}{l}\text { Grindstone study, using } \\
\mathrm{CsCl} \text { extraction. Manioc, } \\
\text { yam, arrowroot and maize } \\
\text { starch identified. Earliest } \\
\text { direct evidence for root crop } \\
\text { cultivation in the Americas. }\end{array}$ \\
\hline 1999 & Davis & $\begin{array}{l}\text { Mleiha, United } \\
\text { Arab Emirates, } \\
\text { 0-2200BP }\end{array}$ & 17 & $\begin{array}{l}500- \\
1000 x\end{array}$ & $\mathrm{Y}$ & - & $\begin{array}{l}\text { In Mleiha. Water extraction } \\
\text { from ground stone artefacts. } \\
\text { Starch found on all artefacts. } \\
\text { Possible Hordeum or Triticum } \\
\text { starch recovered. }\end{array}$ \\
\hline 1999 & $\begin{array}{l}\text { Kealhofer, } \\
\text { Torrence } \\
\text { et al. }\end{array}$ & $\begin{array}{l}\text { FAO, Garua } \\
\text { Island, West } \\
\text { New Britain, } \\
\text { Papua New } \\
\text { Guinea, } \\
\text { modern- } \\
\text { 5900BP } \\
\text { FRL, West New } \\
\text { Britain, Papua } \\
\text { New Guinea, } \\
\text { modern->10ka }\end{array}$ & 14 & $6-500 x$ & $\mathrm{Y}$ & JAS & $\begin{array}{l}\text { For both sites, independent } \\
\text { use-wear and phytolith } \\
\text { studies assessed the value } \\
\text { of phytolith residue analysis. } \\
\text { Identified collagen, starch, } \\
\text { fibres, resin, phytoliths. } \\
\text { Results used to discuss } \\
\text { changes in tool use over time. }\end{array}$ \\
\hline 1999 & $\begin{array}{l}\text { Shanks, } \\
\text { Kornfeld et } \\
\text { al. }\end{array}$ & $\begin{array}{l}\text { Bugas-Holding, } \\
\text { Wyoming, USA, } \\
\text { 200-500BP }\end{array}$ & 46 & $50-100 x$ & $Y$ & JAS & $\begin{array}{l}17 \text { tools displayed visible } \\
\text { microscopic residues, } \\
\text { recorded as presence/ } \\
\text { absence only. Immunological } \\
\text { tests for blood then carried } \\
\text { out. }\end{array}$ \\
\hline 1998 & $\begin{array}{l}\text { Atchison \& } \\
\text { Fullagar }\end{array}$ & $\begin{array}{l}\text { Jinmium, NT, } \\
\text { Australia }\end{array}$ & 3 & $500 x$ & - & - & $\begin{array}{l}\text { In A Closer Look. Examined } \\
\text { three grinding tools for starch } \\
\text { by water extraction and } \\
\text { removal to microscope slide. } \\
\text { Dates uncertain. }\end{array}$ \\
\hline 1998 & $\begin{array}{l}\text { Attenbrow, } \\
\text { Fullagar et al. }\end{array}$ & $\begin{array}{l}\text { SE Australia, } \\
<900 B P\end{array}$ & 28 & $10-1000 x$ & $\mathrm{Y}$ & - & $\begin{array}{l}\text { In A Closer Look. Examined } \\
\text { stone 'fish-hook files' for } \\
\text { evidence of shell-working. } \\
\text { Found some shell residues, } \\
\text { also plant. }\end{array}$ \\
\hline
\end{tabular}




\begin{tabular}{|c|c|c|c|c|c|c|c|}
\hline Year & Author(s) & $\begin{array}{l}\text { Site, age } \\
\text { (approx.) }\end{array}$ & $\#^{1}$ & Mag. $^{2}$ & $U-w^{3}$ & Journal $^{4}$ & Summary \\
\hline 1998 & $\begin{array}{l}\text { Barton, } \\
\text { Torrence } \\
\text { et al. }\end{array}$ & $\begin{array}{l}\text { Garua Is., } \\
\text { Papua New } \\
\text { Guinea, 200- } \\
\text { 5000BP }\end{array}$ & 14 & $200 x$ & $\mathrm{Y}$ & JAS & $\begin{array}{l}\text { Residues removed from } \\
\text { obsidian artefacts by } \\
\text { sonication, as a concurrent } \\
\text { use-wear 'blind test' was } \\
\text { being conducted. Starches } \\
\text { quantified but not identified. }\end{array}$ \\
\hline 1998 & Brass & $\begin{array}{l}\text { Kafiavana, } \\
\text { Papua New } \\
\text { Guinea, } \\
<10.7 \mathrm{ka}\end{array}$ & 200 & $6-1000 x$ & $Y$ & - & $\begin{array}{l}\text { In A Closer Look. Identified } \\
\text { residues in four categories - } \\
\text { plant, blood, plant/blood and } \\
\text { undiagnostic. Blood tested } \\
\text { by subsequent Hemastix and } \\
\text { immunology. 'Plant' includes } \\
\text { starch and plant fibres. }\end{array}$ \\
\hline 1998 & Garling & $\begin{array}{l}\text { Cuddie Springs, } \\
\text { NSW, Australia }\end{array}$ & 4 & $100-500 x$ & $\mathrm{~N}$ & - & $\begin{array}{l}\text { In A Closer Look. Microscopy } \\
\text { used to identify possible blood } \\
\text { residues, then haemoglobin } \\
\text { crystallisation used to attempt } \\
\text { species identification. No } \\
\text { dates provided. }\end{array}$ \\
\hline 1998 & Hardy & $\begin{array}{l}\text { Starosele, } \\
\text { Crimea, } \\
\text { Ukraine, 40- } \\
\text { 80ka }\end{array}$ & 116 & $100-500 x$ & $\mathrm{Y}$ & - & $\begin{array}{l}\text { In The Middle Paleolithic } \\
\text { of the Western Crimea. } \\
\text { Residues classified initially } \\
\text { as plant/animal. Identified } \\
\text { starch, plant tissue, raphides, } \\
\text { possible mastic, hair and } \\
\text { feather. See Hardy and } \\
\text { Kay (1998) for combined } \\
\text { discussion of use-wear and } \\
\text { residue results. }\end{array}$ \\
\hline 1998 & Loy & $\begin{array}{l}\text { Hauslabjoch, } \\
\text { Italy, 5300BP }\end{array}$ & 6 & $50-1000 x$ & $\mathrm{Y}$ & NS & $\begin{array}{l}\text { Identified feather, blood, hair, } \\
\text { collagen, plant hairs on the } \\
\text { stone component of the toolkit } \\
\text { of Otzi the Iceman. }\end{array}$ \\
\hline 1998 & Loy \& Dixon & $\begin{array}{l}\text { Various sites, } \\
\text { Eastern } \\
\text { Beringia }\end{array}$ & 36 & $\begin{array}{l}200- \\
1000 x\end{array}$ & $\mathrm{~N}$ & Am Ant & $\begin{array}{l}\text { No dates provided. Observed } \\
\text { blood film, red blood cells } \\
\text { on Beringian fluted points. } \\
\text { Immunological and DNA tests } \\
\text { confirmed mammalian blood, } \\
\text { including mammoth. }\end{array}$ \\
\hline 1998 & $\begin{array}{l}\text { Piperno \& } \\
\text { Holst }\end{array}$ & $\begin{array}{l}\text { Central } \\
\text { Panama, 1.3- } \\
7 \mathrm{ka}\end{array}$ & 13 & $\begin{array}{l}100- \\
1000 x\end{array}$ & $\mathrm{~N}$ & JAS & $\begin{array}{l}\text { Observed manioc, maize, } \\
\text { arrowroot, and legume } \\
\text { starches, as well as Zea sp. } \\
\text { and palm phytoliths. }\end{array}$ \\
\hline 1998 & $\begin{array}{l}\text { Wallis \& } \\
\text { O'Connor }\end{array}$ & $\begin{array}{l}\text { Widgingarri } \\
\text { Shelters } 1 \\
\text { and } 2 \text {, WA, } \\
\text { Australia, } \\
<4970 \mathrm{BP}\end{array}$ & 42 & - & - & - & $\begin{array}{l}\text { In A Closer Look. Examined } \\
\text { stone points for residues. } \\
\text { No magnification information } \\
\text { provided. Worked material } \\
\text { assessed as plant/animal. }\end{array}$ \\
\hline 1997 & $\begin{array}{l}\text { Fullagar \& } \\
\text { David }\end{array}$ & $\begin{array}{l}\text { Ngarrabullgan } \\
\text { Cave, Qld, } \\
\text { Australia, 930- } \\
\text { 5400BP and } \\
\text { 32.5->37.2ka }\end{array}$ & 257 & $25-1000 x$ & $\mathrm{Y}$ & CAJ & $\begin{array}{l}\text { Found hair, blood, starch, } \\
\text { feather, collagen; results are } \\
\text { presented as plant/animal. } \\
\text { Discusses implications for } \\
\text { social perceptions of the site. }\end{array}$ \\
\hline 1997 & $\begin{array}{l}\text { Fullagar \& } \\
\text { Field }\end{array}$ & $\begin{array}{l}\text { Cuddie Springs, } \\
\text { NSW, Australia, } \\
\text { modern-33ka }\end{array}$ & 33 & $\begin{array}{l}\text { Up to } \\
1000 x\end{array}$ & $\mathrm{Y}$ & Antiquity & $\begin{array}{l}\text { Found distinctive phytoliths, } \\
\text { generally small starches } \\
\text { and blood films on grinding } \\
\text { stones. Contact material } \\
\text { presented as plant/animal. }\end{array}$ \\
\hline 1997 & $\begin{array}{l}\text { Veth, } \\
\text { Fullagar et al. }\end{array}$ & $\begin{array}{l}\text { Puntutjarpa } \\
\text { Rockshelter, } \\
\text { WA, Australia, } \\
\text { 435-10,170BP }\end{array}$ & 2 & - & $\mathrm{Y}$ & AA & $\begin{array}{l}\text { No information reported on } \\
\text { methods or magnification. } \\
\text { Starch was observed on two } \\
\text { grindstone fragments. }\end{array}$ \\
\hline 1997 & Williamson & $\begin{array}{l}\text { Rose Cottage } \\
\text { Cave, South } \\
\text { Africa, 9.5- } \\
13.5 \mathrm{ka}\end{array}$ & 30 & - & $\mathrm{Y}$ & SAJS & $\begin{array}{l}\text { Follows from and combined } \\
\text { with data reported in } \\
\text { Williamson (1996); reports } \\
\text { plant/animal processing } \\
\text { and DNA extraction (not } \\
\text { sequencing) }\end{array}$ \\
\hline
\end{tabular}




\begin{tabular}{|c|c|c|c|c|c|c|c|}
\hline Year & Author(s) & $\begin{array}{l}\text { Site, age } \\
\text { (approx.) }\end{array}$ & $\#^{1}$ & Mag. $^{2}$ & $U-w^{3}$ & Journal $^{4}$ & Summary \\
\hline 1996 & Sobolik & $\begin{array}{l}\text { Hinds Cave, } \\
\text { Texas, USA, } \\
2-5 k a\end{array}$ & 55 & $10-400 x$ & $\mathrm{Y}$ & JFA & $\begin{array}{l}\text { Residues observed at } 10- \\
15 x \text { in situ, then removed } \\
\text { with a wooden scraper and } \\
\text { examined at up to } 400 x \text {. }\end{array}$ \\
\hline 1996 & Williamson & $\begin{array}{l}\text { Rose Cottage } \\
\text { Cave, South } \\
\text { Africa, 6ka }\end{array}$ & 167 & $50-500 x$ & $\mathrm{Y}$ & SAFA & $\begin{array}{l}\text { Reports plant/animal } \\
\text { processing, with a } \\
\text { predominance of plant. } \\
\text { Fungal residues were found } \\
\text { on one third of artefacts, } \\
\text { and non-formal tools had } \\
\text { residues. }\end{array}$ \\
\hline 1995 & $\begin{array}{l}\text { Tuross \& } \\
\text { Dillehay }\end{array}$ & $\begin{array}{l}\text { Monte Verde, } \\
\text { Chile, 12.5- } \\
\text { 13.2+ka }\end{array}$ & 7 & $4-20 x$ & $\mathrm{~N}$ & JFA & $\begin{array}{l}\text { Residues screened via } \\
\text { microscopy, but analyses } \\
\text { conducted using immunology } \\
\text { - no correlation between } \\
\text { observed 'stains' and } \\
\text { immunological results }\end{array}$ \\
\hline 1994 & Loy & $\begin{array}{l}\text { Mustang } \\
\text { Branch and } \\
\text { Barton sites, } \\
\text { Texas, USA }\end{array}$ & 108 & $\begin{array}{l}100- \\
1000 x\end{array}$ & $Y$ & - & $\begin{array}{l}\text { In Human Ecology in the } \\
\text { Middle Onion Creek Valley. } \\
\text { Results reported as plant/ } \\
\text { animal, with additional } \\
\text { chemical tests (also examined } \\
40 \text { burned rocks). }\end{array}$ \\
\hline 1993 & $\begin{array}{l}\text { Barton \& } \\
\text { White }\end{array}$ & $\begin{array}{l}\text { Balof 2, New } \\
\text { Ireland, Papua } \\
\text { New Guinea, } \\
<14 \text { ka }\end{array}$ & 21 & $>100 x$ & $\mathrm{Y}$ & AP & $\begin{array}{l}\text { Identified tuber processing } \\
\text { on most artefacts over the } \\
14,000 \text { year period. Animal } \\
\text { residues were not present. }\end{array}$ \\
\hline 1993 & Boot & $\begin{array}{l}\text { Graman, NSW, } \\
\text { Australia, } \\
\text { 2-5.5ka }\end{array}$ & 2722 & $24-1000 x$ & $Y$ & - & $\begin{array}{l}\text { In Archaeometry: Current } \\
\text { Australasian research. Initial } \\
\text { low-magnification screening } \\
\text { showed } 720 \text { artefacts with } \\
\text { evidence of use, } 165 \text { had use } \\
\text { or hafting residues. }\end{array}$ \\
\hline 1993 & Fullagar & $\begin{array}{l}\text { West New } \\
\text { Britain, Papua } \\
\text { New Guinea, } \\
>3.5 \mathrm{ka}\end{array}$ & 43 & - & $\mathrm{Y}$ & - & $\begin{array}{l}\text { In Traces et Fonction. } \\
\text { Identified starch grains, } \\
\text { phytoliths and blood. } \\
\text { Discusses plant vs animal } \\
\text { processing, change over time, } \\
\text { and phytoliths in particular. No } \\
\text { magnifications provided. }\end{array}$ \\
\hline 1993 & Fullagar & $\begin{array}{l}\text { West New } \\
\text { Britain, Papua } \\
\text { New Guinea, } \\
>3.5-4 \text { ka }\end{array}$ & 1 & $10-500 x$ & $\mathrm{Y}$ & - & $\begin{array}{l}\text { In Archaeometry: Current } \\
\text { Australasian research. } \\
\text { Recovered phytoliths from } \\
\text { adhering soil, and observed } \\
\text { in situ phytoliths, starch, } \\
\text { raphides, fungal remains and } \\
\text { suspected blood. }\end{array}$ \\
\hline 1993 & $\begin{array}{l}\text { Furby, } \\
\text { Fullagar et al. }\end{array}$ & $\begin{array}{l}\text { Cuddie Springs, } \\
\text { NSW, Australia, } \\
\text { 19-28ka }\end{array}$ & - & - & $\mathrm{Y}$ & - & $\begin{array}{l}\text { In Sahul in Review. Few } \\
\text { specific details of the study } \\
\text { provided. Red blood cells, } \\
\text { animal tissue, mammalian } \\
\text { hair and woodworking/plant } \\
\text { processing residues identified } \\
\text { on flaked stone. Starch found } \\
\text { on a grindstone. }\end{array}$ \\
\hline 1993 & Loy & $\begin{array}{l}\text { Toad River } \\
\text { Canyon, } \\
\text { Canada, } \\
2200 B P\end{array}$ & 11 & - & $\mathrm{N}$ & WA & $\begin{array}{l}\text { Identified blood/hair/animal } \\
\text { tissue, as well as some plant } \\
\text { remains. Immunological } \\
\text { and DNA tests were then } \\
\text { employed. }\end{array}$ \\
\hline
\end{tabular}




\begin{tabular}{|c|c|c|c|c|c|c|c|}
\hline Year & Author(s) & $\begin{array}{l}\text { Site, age } \\
\text { (approx.) }\end{array}$ & $\#^{1}$ & Mag. ${ }^{2}$ & $U-w^{3}$ & Journal $^{4}$ & Summary \\
\hline 1992 & Fullagar & $\begin{array}{l}\text { FEA, West New } \\
\text { Britain, Papua } \\
\text { New Guinea, } \\
\text { recent-3500BP } \\
\text { FRL, West } \\
\text { New Britain, } \\
\text { Papua New } \\
\text { Guinea, recent- } \\
\text { >3500BP } \\
\text { FRI, West New } \\
\text { Britain, Papua } \\
\text { New Guinea, } \\
\text { recent-3500BP } \\
\text { FOF, West New } \\
\text { Britain, Papua } \\
\text { New Guinea, } \\
\text { 2000->3500BP } \\
\text { FHC, West } \\
\text { New Britain, } \\
\text { Papua New } \\
\text { Guinea, recent- } \\
\text { >3500BP } \\
\text { FGT, West } \\
\text { New Britain, } \\
\text { Papua New } \\
\text { Guinea, recent- } \\
\text { >3500BP }\end{array}$ & 63 & $6-500 x$ & $\bar{Y}$ & - & $\begin{array}{l}\text { In Poterie Lapita et } \\
\text { Peuplement. Studied } \\
\text { obsidian flakes from six sites, } \\
\text { divided into three phases } \\
\text { based on Lapita occupation. } \\
\text { Results presented as plant } \\
\text { vs animal processing, with } \\
\text { discussion of changes in } \\
\text { resource exploitation and site } \\
\text { specialisation. }\end{array}$ \\
\hline 1992 & $\begin{array}{l}\text { Fullagar, } \\
\text { Meehan et al. }\end{array}$ & $\begin{array}{l}\text { Various sites, } \\
\text { Northern } \\
\text { Australia, <2ka }\end{array}$ & 72 & $<300 x$ & $\mathrm{Y}$ & - & $\begin{array}{l}\text { In Prehistorie de l'Agriculture. } \\
\text { Examined a variety of } \\
\text { ethnographic and recent } \\
\text { archaeological artefact } \\
\text { materials (72 of which were } \\
\text { archaeological stone). Plant } \\
\text { and animal identifications. }\end{array}$ \\
\hline 1992 & Hurcombe & $\begin{array}{l}\text { Ortu Comidu, } \\
\text { Sardinia, } \\
\text { 2-3.5ka }\end{array}$ & 12 & $250-625 x$ & $\mathrm{Y}$ & - & $\begin{array}{l}\text { In Use-wear Analysis } \\
\text { and Obsidian. Residue } \\
\text { morphology is described, } \\
\text { rather than assigned to } \\
\text { particular origins; possible } \\
\text { plant. }\end{array}$ \\
\hline 1992 & Loy \& Hardy & $\begin{array}{l}\text { Tabun Cave, } \\
\text { Israel, 90ka }\end{array}$ & 10 & $12-1000 x$ & $\mathrm{~N}$ & Antiquity & $\begin{array}{l}\text { Microscopic and } \\
\text { immunological study of blood } \\
\text { residues. Concludes tools } \\
\text { used for (unspecified) animal } \\
\text { processing. }\end{array}$ \\
\hline 1992 & $\begin{array}{l}\text { Loy, Spriggs } \\
\text { et al. }\end{array}$ & $\begin{array}{l}\text { Kilu Cave, } \\
\text { Solomon is., } \\
<9 k a \& \text { 20- } \\
28.7 \mathrm{ka}\end{array}$ & 47 & $\begin{array}{l}500- \\
1000 x\end{array}$ & $\mathrm{Y}$ & Antiquity & $\begin{array}{l}\text { Identified taro (Colocasia } \\
\text { esculenta and Alocasia } \\
\text { macrorrhiza) starch grains } \\
\text { and raphides. }\end{array}$ \\
\hline 1992 & Sievert & $\begin{array}{l}\text { Chichen Itza, } \\
\text { Mexico }\end{array}$ & 166 & $50-200 x$ & $\mathrm{Y}$ & - & $\begin{array}{l}\text { In Maya Ceremonial } \\
\text { Specialization. No specific } \\
\text { dates available, although } \\
\text { likely >500BP. Identified } \\
\text { resins, gold, pigment, plant } \\
\text { tissue, possible blood on } \\
\text { artefacts that had previously } \\
\text { been chemically cleaned. See } \\
\text { also Sievert (1990, 1992b). }\end{array}$ \\
\hline 1991 & Loy & $\begin{array}{l}\text { Unspecified } \\
\text { Moa butchery } \\
\text { sites, New } \\
\text { Zealand, } \\
\text { 1000BP }\end{array}$ & 20 & - & - & - & $\begin{array}{l}\text { In Archaeometry '90. Very } \\
\text { little information - no data on } \\
\text { techniques or sites. Identified } \\
\text { moa feather fragments on } 5 \\
\text { tools. }\end{array}$ \\
\hline
\end{tabular}




\begin{tabular}{|c|c|c|c|c|c|c|c|}
\hline Year & Author(s) & $\begin{array}{l}\text { Site, age } \\
\text { (approx.) }\end{array}$ & $\#^{1}$ & Mag. $^{2}$ & $U-w^{3}$ & Journal $^{4}$ & Summary \\
\hline 1990 & $\begin{array}{l}\text { Hyland, } \\
\text { Tersak et al. }\end{array}$ & $\begin{array}{l}\text { Shoop, Illinois, } \\
\text { USA, 8ka }\end{array}$ & 45 & $<10 x$ & $\mathrm{~N}$ & Am. Ant. & $\begin{array}{l}\text { Very low magnification } \\
\text { initial screening of artefacts } \\
\text { for subsequent Hemastix } \\
\text { and immunological testing } \\
\text { for blood. One artefact } \\
\text { possessed blood (cervid) } \\
\text { residue. }\end{array}$ \\
\hline 1990 & Jones & $\begin{array}{l}\text { Kutikina Cave, } \\
\text { Tasmania, } \\
\text { Australia, 15- } \\
\text { 17ka }\end{array}$ & - & - & $\mathrm{Y}$ & - & $\begin{array}{l}\text { In The World at 18,000BP. } \\
\text { Few details provided (no } \\
\text { magnifications, number of } \\
\text { tools). Found evidence of } \\
\text { meat, bone, plant and wood } \\
\text { working. }\end{array}$ \\
\hline 1990 & Loy & $\begin{array}{l}\text { Lake Mungo, } \\
\text { NSW, Australia, } \\
\text { 20-35ka. }\end{array}$ & - & - & $\mathrm{Y}$ & $\mathrm{ANH}$ & $\begin{array}{l}\text { No details of methods and } \\
\text { number of tools examined } \\
\text { are provided. Identified starch } \\
\text { grains and plant tissue, blood, } \\
\text { sinew and periosteum. }\end{array}$ \\
\hline 1989 & Fullagar & $\begin{array}{l}\text { Ritamauda } \\
\text { rockshelter } \\
\text { (QBB), Papua } \\
\text { New Guinea, } \\
\text { 0-3500BP } \\
\end{array}$ & 161 & $6-400 x$ & $\mathrm{Y}$ & - & $\begin{array}{l}\text { In A Crack in the Spine. } \\
\text { Found organic smears and } \\
\text { fragments, fibres, plant tissue, } \\
\text { silica particles. Palm, reed } \\
\text { and wood working inferred. }\end{array}$ \\
\hline 1989 & $\begin{array}{l}\text { Hall, Higgins } \\
\text { et al. }\end{array}$ & $\begin{array}{l}\text { SE } \\
\text { Queensland, } \\
\text { Australia }\end{array}$ & 10 & $6-400 x$ & $\mathrm{Y}$ & - & $\begin{array}{l}\text { In Plants in Australian } \\
\text { Archaeology. No dates } \\
\text { provided. Found starches } \\
\text { and plant tissue on pounding } \\
\text { tools (and slides made from } \\
\text { the tools). }\end{array}$ \\
\hline 1989 & Loy \& Wood & $\begin{array}{l}\text { Cayonu Tepesi, } \\
\text { Turkey, 6.8- } \\
\text { 7.4ka }\end{array}$ & 398 & - & $\mathrm{N}$ & JFA & $\begin{array}{l}\text { No details of magnification. } \\
\text { Artefacts were screened } \\
\text { microscopically in the field for } \\
\text { blood, then residues removed } \\
\text { for lab testing. Identified } \\
\text { human, auroch and Ovis sp. } \\
\text { blood. }\end{array}$ \\
\hline 1989 & $\begin{array}{l}\text { Newman \& } \\
\text { Julig }\end{array}$ & $\begin{array}{l}\text { Cummins site, } \\
\text { Thunder Bay, } \\
\text { Canada, 7.5- } \\
\text { 9ka }\end{array}$ & 36 & $10-40 x$ & $\mathrm{~N}$ & CJA & $\begin{array}{l}\text { Artefacts initially screened } \\
\text { using low-power microscopy. } \\
\text { Potential blood residues } \\
\text { identified, then tested } \\
\text { immunologically. }\end{array}$ \\
\hline 1989 & Richards & $\begin{array}{l}\text { Thorpe } \\
\text { Common } \\
\text { rockshelter, } \\
\text { Yorkshire, UK, } \\
5.7-6.4 \mathrm{ka}\end{array}$ & 50 & $10-625 x$ & $\mathrm{~N}$ & - & $\begin{array}{l}\text { In Breaking the Stony } \\
\text { Silence. Blood residues } \\
\text { identified on } 41 \text { tools through } \\
\text { microscopy and chemstrip } \\
\text { testing. Observed blood also } \\
\text { in the soil matrix immediately } \\
\text { adhering to some artefacts. }\end{array}$ \\
\hline 1988 & Fullagar & $\begin{array}{l}\text { Aire Shelter } \\
\text { II, Victoria, } \\
\text { Australia, } \\
\text { <600BP }\end{array}$ & 1814 & - & $\mathrm{Y}$ & - & $\begin{array}{l}\text { In Industries Lithique. } \\
\text { Study reported briefly, no } \\
\text { magnifications provided. } \\
\text { Residues on } 13 \text { tools, } \\
\text { including collagen. }\end{array}$ \\
\hline 1987 & Fullagar & $\begin{array}{l}\text { Birrigai } \\
\text { rockshelter, } \\
\text { ACT, Australia, } \\
<1000- \\
21000 \mathrm{BP}\end{array}$ & 69 & - & $\mathrm{Y}$ & $\mathrm{AO}$ & $\begin{array}{l}\text { Identified residues on } 9 \text { of the } \\
69 \text { artefacts. Found blood, } \\
\text { collagen, plant and possible } \\
\text { ochre. Blood may not be from } \\
\text { tool-use. No magnifications } \\
\text { provided. }\end{array}$ \\
\hline 1987 & Jones & $\begin{array}{l}\text { Kutikina Cave, } \\
\text { Tasmania, } \\
\text { Australia, 17- } \\
20 \text { ka }\end{array}$ & 1 & $300 x$ & $\mathrm{Y}$ & AG & $\begin{array}{l}\text { No information on number } \\
\text { of artefacts analysed (only } \\
\text { the results from one are } \\
\text { reported). Found collagen and } \\
\text { blood identified as red-necked } \\
\text { wallaby. }\end{array}$ \\
\hline
\end{tabular}




\begin{tabular}{|c|c|c|c|c|c|c|c|}
\hline Year & Author(s) & $\begin{array}{l}\text { Site, age } \\
\text { (approx.) }\end{array}$ & $\#^{1}$ & Mag. $^{2}$ & $U-w^{3}$ & Journal $^{4}$ & Summary \\
\hline 1987 & Loy & $\begin{array}{l}\text { Barda Balka, } \\
\text { Iraq, 75-125ka; } \\
\text { Jarmo, Iran, } \\
\text { 8-10ka; } \\
\text { Unspecified } \\
\text { site, Belgium, } \\
\text { 20ka }\end{array}$ & $\begin{array}{l}5 \\
2\end{array}$ & - & - & - & $\begin{array}{l}\text { In Archaeometry: Further } \\
\text { Australasian Studies. Three } \\
\text { studies mentioned very briefly } \\
\text { - little detail on methods or } \\
\text { results. Found blood cells and } \\
\text { mammalian blood deposits. }\end{array}$ \\
\hline 1985 & Frederickson & $\begin{array}{l}\text { Whakamoenga } \\
\text { Cave, New } \\
\text { Zealand; } \\
\text { Twilight Beach, } \\
\text { New Zealand }\end{array}$ & $\begin{array}{l}138 \\
61\end{array}$ & $15-50 x$ & $\mathrm{~N}$ & NZAAN & $\begin{array}{l}\text { No dates provided. Examined } \\
\text { obsidian flakes from two } \\
\text { sites for blood residues via } \\
\text { light microscopy, test-strips } \\
\text { and SEM. Light microscopy } \\
\text { identified fibrous material, and } \\
\text { deposits of various colours. } \\
\text { Subsequent SEM identified } \\
\text { erythrocytes. }\end{array}$ \\
\hline 1985 & Loy & $\begin{array}{l}\text { Hidden Cave, } \\
\text { Nevada, USA }\end{array}$ & 1 & $5-800 x$ & $\mathrm{~N}$ & - & $\begin{array}{l}\text { In The Archaeology of Hidden } \\
\text { Cave. No dates provided. } \\
\text { Identified bat hair and } \\
\text { presumed bat blood, as well } \\
\text { as feather barbules. }\end{array}$ \\
\hline 1984 & McBryde & $\begin{array}{l}\text { Graman, NSW, } \\
\text { Australia, 1-5ka }\end{array}$ & - & - & $\mathrm{Y}$ & - & $\begin{array}{l}\text { In Recent Advances in Indo- } \\
\text { Pacific Prehistory. No data on } \\
\text { magnifications provided. It is } \\
\text { unclear how many artefacts } \\
\text { were examined (possibly } \\
900 \text { ). Identified hafting 'stains' } \\
\text { on } 26 \text { backed blades from } 3 \\
\text { sites. }\end{array}$ \\
\hline 1983 & Loy & $\begin{array}{l}\text { Various sites, } \\
\text { Canada, 1-6ka }\end{array}$ & 104 & $12-500 x$ & - & Science & $\begin{array}{l}\text { Blood residues observed on } \\
90 \text { artefacts, as identified by } \\
\text { a variety of tests; species } \\
\text { identified via haemoglobin } \\
\text { crystallisation. }\end{array}$ \\
\hline 1982 & $\begin{array}{l}\text { Coughin \& } \\
\text { Claassen }\end{array}$ & $\begin{array}{l}\text { Vail, Maine, } \\
\text { USA, Palaeo- } \\
\text { Indian }\end{array}$ & 27 & $160 x$ & $\mathrm{~N}$ & - & $\begin{array}{l}\text { In The Vail Site. Initial in situ } \\
\text { observation of 'tiny biological } \\
\text { fragments', followed by } \\
\text { removal to slides. Observed } \\
\text { well-preserved phytoliths, and } \\
\text { plant tissue. }\end{array}$ \\
\hline 1979 & $\begin{array}{l}\text { Shafer \& } \\
\text { Holloway }\end{array}$ & $\begin{array}{l}\text { Hinds Cave, } \\
\text { Texas, USA, } \\
\text { 2-5ka }\end{array}$ & 25 & $10-400 x$ & $\mathrm{Y}$ & - & $\begin{array}{l}\text { In Lithic Use-wear Analysis. } \\
\text { Initial observation of plant } \\
\text { fibres and epidermis in situ, } \\
\text { then removal to slides (for } \\
11 \text { tools). Found phytoliths, } \\
\text { hairs, starch, and more, some } \\
\text { identifiable to species }\end{array}$ \\
\hline 1976 & Briuer & $\begin{array}{l}\text { Chevelon } \\
\text { Canyon and } \\
\text { Cayote Creek } \\
\text { Pueblo, } \\
\text { Arizona, USA, } \\
\text { 700-8700BP }\end{array}$ & 2551 & $30 x$ & $\mathrm{Y}$ & Am Ant & $\begin{array}{l}\text { Used low-magnification to } \\
\text { screen artefacts, found } 37 \\
\text { with 'organic use residues'. } \\
\text { These were classified } \\
\text { (using chemical tests and } \\
\text { morphological inspection) as } \\
\text { plant or animal. }\end{array}$ \\
\hline
\end{tabular}

$1: \#=$ the number of artefacts examined. This number is often much larger than the number of artefacts with residues. 2: Mag. = magnifications used by the analyst.

3: $\mathrm{U}-\mathrm{w}=$ whether or not use-wear was also examined in the study [ $\mathrm{Y}=$ yes; $\mathrm{N}=$ no; - = insufficient information].

4: Journal = the journal in which the study was published. See below for abbreviations. If the study was not published in a journal, the source is listed in the 'Summary' column. 
Journal abbreviations:

AA Australian Archaeology

AAS Australian Aboriginal Studies

AG Australian Geographic

Am Ant American Antiquity

ANH Australian Natural History

AO Archaeology in Oceania

AP Asian Perspectives

CAJ Cambridge Archaeological Journal

CJA Canadian Journal of Archaeology

HA Hawaiian Archaeology

JAS Journal of Archaeological Science

JFA Journal of Field Archaeology

JHE Journal of Human Evolution

JNAS Journal of Nordic Archaeological Science
LAA Latin American Antiquity

NS New Scientist

NZAAN New Zealand Archaeological Association Newsletter

NZJA New Zealand Journal of Archaeology

PNAS Proceedings of the National Academy of Sciences

RAM Records of the Australian Museum

RPP Review of Palaeobotany and Palynology

SAAB South African Archaeological Bulletin

SAFA South African Field Archaeology

SAH Southern African Humanities

SAJS South African Journal of Science

VHA Vegetation History and Archaeobotany

WA World Archaeology 